\title{
基礎講座
}

\section{金属系超電導線材 [2]}

一合金系線材一

太刀川恭治*

\section{Metallic Superconductors [2] \\ - Superconducting Alloy Wires -}

\author{
Kyoji TACHIKAWA ${ }^{*}$
}

Synopsis The procedure for mass producing Nb-Ti alloy has been established, where the development of high-homogeneity ingots improves the reliability of the alloy. The manufacturing process of fine filamentary wires of long length has also been optimized. The Nb-Ti wires can be used up to $9 \mathrm{~T}$ at $4.2 \mathrm{~K}$. The non- $\mathrm{Cu} \mathrm{J}_{\mathrm{c}}$ of the wires at $6 \mathrm{~T}$ and $4.2 \mathrm{~K}$ reaches $2,500 \mathrm{~A} / \mathrm{mm}^{2}$ through the combination of cold drawing and heat treatment. The microstructure of resulting Nb-Ti wires is very complicated, containing dislocation sub-bands and $\alpha$-Ti precipitations. The structure and flux pinning in fine filamentary wires have been studied in detail. The introduction of artificial pinning centers, for example Nb, yields an appreciable increase in $J_{c}$. Ultra-thin filamentary Nb-Ti wires with low AC loss have also been successfully fabricated. Nb-Ti based ternary alloys, for example $\mathrm{Nb}-\mathrm{Ti}$-Ta and Nb-Ti-Hf, have been studied, aiming for the enhancement of $\mathrm{B}_{\mathrm{c} 2}$. The microstructure and performance of alloys other than Nb-Ti, for example Nb-Zr, V-Ti and Mo-Re, are also described in this article.

Keywords Nb-Ti, fabrication procedure, microstructure, superconducting performance, AC-use wire

\section{1. はじめに}

合金系線材としては、周期律表 $\mathrm{V}$ 族の $\mathrm{V} 、 \mathrm{Nb} 、 \mathrm{Ta}$ に $\mathrm{IV}$ 族 の Ti、Zr、Hf を組み合わせた合金が主流となっている。そ の他 Mo-Re 系やPb-Bi 系合金等も研究されている。しかし、 合金系線材すなわち Nb-Ti 線といってよいのが現状であり、 これまでの開発の経緯については前回の講座で述べた ${ }^{1)}$ 。 現在その世界における生産量は 2,000 ton/年程度と考えら れる。

$\mathrm{Nb}-\mathrm{Ti}$ 系合金の他の金属系超伝導線材に対する長所は、 大型のインゴットが生産出来ること、安定化のための $\mathrm{Cu}$ との複合加工の容易なこと、機械的歪みによる特性変化が 小さいことなどが挙げられ、その結果大量生産に適して安 価なことが大きい利点である。Nb-Ti 合金線材は MRI 診断 装置、粒子加速器、核融合装置に大量に用いられ、また $\mathrm{Nb}_{3} \mathrm{Sn}$ 高磁界マグネットのバックアップコイルにも広く用

\footnotetext{
Received December 10, 2009

*東海大学工学部

干259-1292 神奈川県平塚市北金目 1117

Faculty of Engineering, Tokai University,

1117 Kitakaname, Hiratuka, Kanagawa 259-1292, Japan

E-mail: tacsuper@keyaki.cc.u-tokai.ac.jp
}

いられている。産業分野では半導体引上げ装置、電力貯蔵 装置 (SMES)、リニアモーターカー等に実績を上げている。

文献 ${ }^{1)}$ に示したように $\mathrm{Nb}-\mathrm{Ti}$ の臨界温度 $\mathrm{T}_{\mathrm{c}}$ は $\mathrm{Nb}$ と大差 ないが、上部臨界磁界 $\mathrm{B}_{\mathrm{c} 2}(4.2 \mathrm{~K})$ は $11.4 \mathrm{~T}$ で $9 \mathrm{~T}$ の磁界 発生にまで用いられる。 $\mathrm{B}_{\mathrm{c} 2}$ の上昇が $\mathrm{Ta} 、 \mathrm{Zr} 、 \mathrm{Hf}$ 等の添加 により研究されたが、1.7〜 $2.0 \mathrm{~K}$ での高磁界特性が若干改 善される程度である。 Nb-Ti 合金線の $\mathrm{B}_{\mathrm{c} 2}$ の向上にはさらに 新たな方策が必要と考えられる。

$\mathrm{Nb}-\mathrm{Ti}$ 合金線の実用上は臨界電流密度 Jc の向上が強く求 められた。Nb-Ti 合金線における有効なピン止め点は、加 工で生じる転位セル(サブバンド)、 $\alpha-\mathrm{Ti}$ 析出相等があり、 次回に述べる $\mathrm{Nb}_{3} \mathrm{Sn}$ や $\mathrm{V}_{3} \mathrm{Ga}$ に比べはるかに複雑な組織と なる。そのため加工や熱処理条件の最適化が図られた。 $\mathrm{Nb}-\mathrm{Ti}$ 合金線の非銅部（non-Cu）Jcは、4.2 K、6 T で 2,500 $\mathrm{A} / \mathrm{mm}^{2}$ に達する。合金線材組織の制御は後述するように一 つのナノテクであり、新たな研究が望まれる。

$\mathrm{Nb}-\mathrm{Ti}$ 合金線のさらなる $\mathrm{c}$ 向上のため、 $\mathrm{Nb}$ 等の人工ピン の導入も熱心に研究された。一方、交流用線材のため、サ ブミクロンの超極細芯線材の開発が行われ、低ロス線材の 開発に成果を上げた。さらに Cuの代わりに軽量で磁気抵 抗の小さい $\mathrm{Al}$ 安定化材の研究開発も行われている。 


\section{2. $\mathrm{Nb}-\mathrm{Ti}$ 合金線の製造}

\section{2. $1 \mathrm{Nb}$ - $\mathrm{Ti}$ 合金素材の作製}

合金溶製は製造工程の出発点であり、工業化されている 他の材料と同様にその技術の確立に多く研究開発がなさ れた。Nbの融点は〜 $2,470^{\circ} \mathrm{C}$ で高融点のため、その溶解に は引き下げ方式のアーク溶解が用いられる。一方 $\mathrm{Ti}$ の融点 は $1,670^{\circ} \mathrm{C} て ゙ \mathrm{Nb}$ の融点と温度差があるため、組成の均一 性に特に注意が払われた。線材メーカーの要求に応じ、 Nb-45〜 50 wt\%Ti の合金が溶製される。Fig 1 に示すような 消耗電極引き下げ型アーク溶解炉で直径 $200 \mathrm{~mm}$ 、高さ 2,000 mm、重量 $500 \mathrm{~kg}$ 程度のインゴットが溶製される ${ }^{2)}$ 。

インゴット内の充分な組成の均一性を得るため、2 回ま たはそれ以上の溶解が繰り返される。高均一度インゴット 内の $\mathrm{Ti}$ 量の変動は $\pm 0.5 \mathrm{wt} \%$ あ゙ある。Table 1 に Allegheny Technology 社の Nb-Ti インゴット内の不純物の規格と実例 を示した ${ }^{3)}$ 。金属系不純物は原料の $\mathrm{Nb}$ と Ti に含まれるも のと考えられ、これらの原料の高純度化により Nb-Ti 合金 の純度も向上した。合金の加工性の点からはとくにC 等の 侵入型不純物の含有量が少ないことが好ましい。Table 1 で は分離しにくい Ta 含有量が多いが、超電導特性上は問題 ないと考えられる。

インゴットは熱間加工後真空焼鈍されたのち、その表面 が外削りされて 3〜 50 mm 径の棒が製品となる。合金棒の ブリネル硬さは 170 以下とされている。合金棒の品質管理 は、安定化の $\mathrm{Cu}$ と複合後極細芯への加工に支障がないよ うに入念に行われている。内部の小さいボイドやわれ等の 久陥の有無は超音波探傷等によりチェックされる。また極 細フィラメントでいわゆるソーセージングなどの不具合

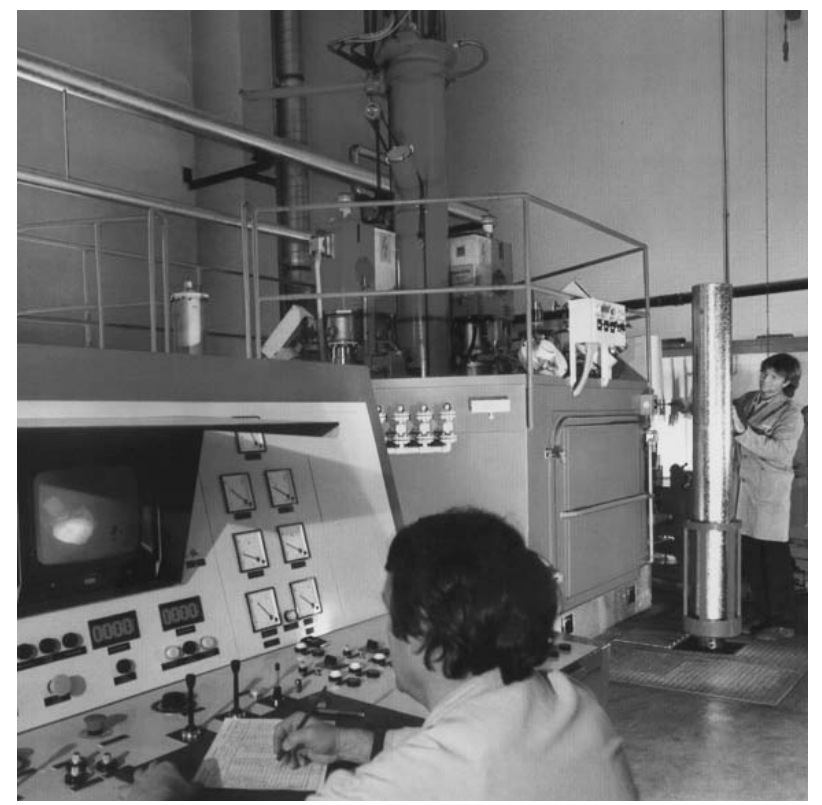

Fig 1 Example of a consumable electrode arc melting furnace. ${ }^{2)}$ The ingot can be seen on the right-hand side.
が生じないように棒材表面の細かい割れ、ふくれなどの傷 は注意深く除かれ、寸法、真円性、直線性等も丁寧に検查 される。

上記のような素材作製と品質管理技術の進歩により 10 $\mu \mathrm{m} \phi$ 以下の極細芯線材の加工にも問題がなく、Nb-Ti 合金 素材の作製技術はほぼ確立しているといえる。また例えば 上述の Allegheny Technology 社は月間約 50 ton の Nb-Ti 合 金素材を作製しており、さらなる大量需要にも対応可能で あるとしている。

\section{$2.2 \mathrm{Nb}-\mathrm{Ti}$ 極細多芯線の作製}

$\mathrm{Nb}-\mathrm{Ti}$ 素材棒は、安定化のための無酸素 $\mathrm{Cu}$ 管に挿入され て単芯ビレットとされる。ビレットの組立作業は通常クリ ーンルームで行われ、Nb-Ti と Cu との良好な金属接触が得 られるように留意される。単芯ビレットは対辺長 $5 \mathrm{~mm}$ 程 度の 6 角棒に加工されたのち、大口径の無酸素 $\mathrm{Cu}$ 管に挿 入されて多芯ビレットが組み立てられる。 Nb-Ti と Cu との 面積比（Cu 比）は 0.5 5.0 で用途に応じて決められる。

大型多芯ビレットの外径は $250 \mathrm{~mm}$ 、長さ $1,000 \mathrm{~mm}$ 程度 となる。Fig 2 に大型加速器の LHC (Large Hadron Collider) 線材用に組み立てられた多芯ビレットの断面を 1 例として 示した ${ }^{4)}$ 。Fig. 2 の中央部は $\mathrm{Cu}$ 棒のみで、その周りに 8,500 本の単芯 6 角ビレットが組み込まれている。この多芯ビレ ットは両端に真空電子ビーム溶接により蓋がはめられ密 封されて組立てが完成する。

多芯ビレットはまず熱間での押出加工により数十 $\mathrm{mm} \phi$ の棒状に加工されたのち、直線的な引抜加工機（ドローペ ンチ)により $10 \mathrm{~mm} \phi$ 程度まで線引される。従ってこの加 工には長尺のドローペンチが必要となる。ついで通常のド ラム巻き取り方式で伸線されるが、ドラム径は線径に応じ たものを用いる。線径が細くなると複数のダイスをセット した線引機で効率的に伸線される。ついで電磁気的な安定 性の向上のためツイストが加えられたのち、撚線機により 種々の断面形状に成形されて最終製品となる。

Table 1 Inclusions in commercial Nb-46/48 wt\% Ti ingot (ppm) ${ }^{3)}$

\begin{tabular}{ccc}
\hline & Specification & Example \\
\hline $\mathrm{C}$ & $<200$ & $<20$ \\
$\mathrm{O}$ & $<1,000$ & 580 \\
$\mathrm{~N}$ & $<150$ & 48 \\
$\mathrm{H}$ & $<35$ & 3 \\
$\mathrm{Fe}$ & $<200$ & 130 \\
$\mathrm{Si}$ & $<100$ & 53 \\
$\mathrm{Ta}$ & $<1,000$ & 590 \\
$\mathrm{Cr}$ & $<60$ & $<30$ \\
$\mathrm{Ni}$ & $<100$ & $<50$ \\
$\mathrm{Cu}$ & $<100$ & $<50$ \\
$\mathrm{Al}$ & $<125$ & $<50$ \\
$\mathrm{Ti}$ & $46 / 48 \%$ & 47.2 \\
$\mathrm{Nb}$ & Balance & Balance \\
\hline
\end{tabular}




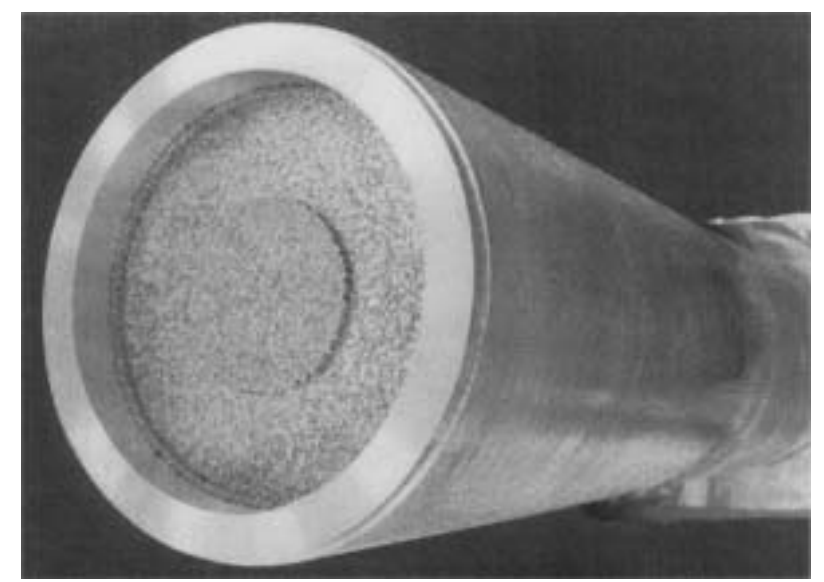

Fig. 2 An assembled billet for extrusion. Outer diam.: 236.5 mm, No. of Nb-Ti cores: 8,500, Center: Cu rod. ${ }^{4)}$

Fig. 2 に示したビレットの場合、まず $0.825 \mathrm{~mm} \phi$ で全長 約 $50 \mathrm{~km}$ に達する素線に伸線される。素線の Cu 比は 1.95、 ツイストピッチ比は $15 \mathrm{~mm}$ である。この素線は $6 \mu \mathrm{m} \phi$ で 8,500 本の Nb-Ti 芯から構成される。ついで、この素線 36 本を用いて Fig. 3 に示すようなラザフォード型ケーブルに 撚線されて製品となる。以上のように、Nb-Ti 合金素材作 製並びに線材加工の基本的技術は完成の域に達している。 今後は種々の新しい用途からの要望に対処した線材作製 が行われるであろう。なお、Nb-Ti 線材の加工技術の詳細 については文献 ${ }^{5)}$ 等がある。

\section{3. $\mathrm{Nb}-\mathrm{Ti}$ 合金線の組織}

Fig. 4 によく知られている $\mathrm{Nb}-\mathrm{Ti}$ 合金系の状態図を示 寸 ${ }^{6)}$ 。 $\mathrm{Nb}$ 側は bcc $の ~ \beta$ 相であるが、Ti 側は六方晶の $\alpha$ 相が 現れる。熱処理では $\beta$ 相から c/a 比約 0.61 の六方晶の $\omega$ 中 間相を経て $\alpha$ 相に変態する。

Fig. 5 に Nb-Ti系の組成による $\mathrm{T}_{\mathrm{c}}$ と $\mathrm{B}_{\mathrm{c} 2}$ の変化を示した。 約 35 at\%（22 wt\%） Ti で $\mathrm{T}_{\mathrm{c}}$ は最高值 $10.1 \mathrm{~K}$ となるが、 $\mathrm{B}_{\mathrm{c} 2}$ の最も高い約 60 at\%（45 wt\%） Ti の実用線材では約 $9 \mathrm{~K}$ と

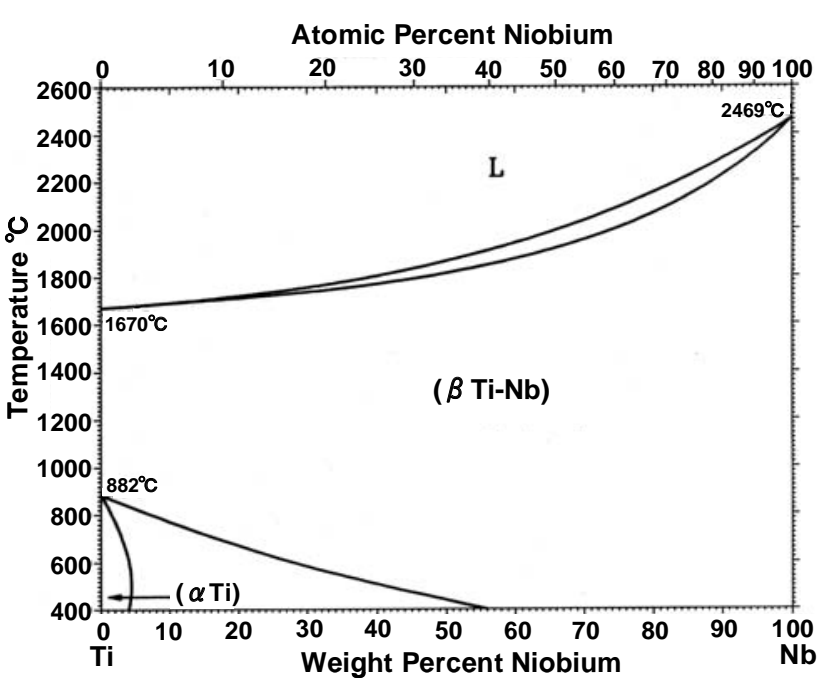

Fig. 4 Nb-Ti phase diagram. ${ }^{6}$

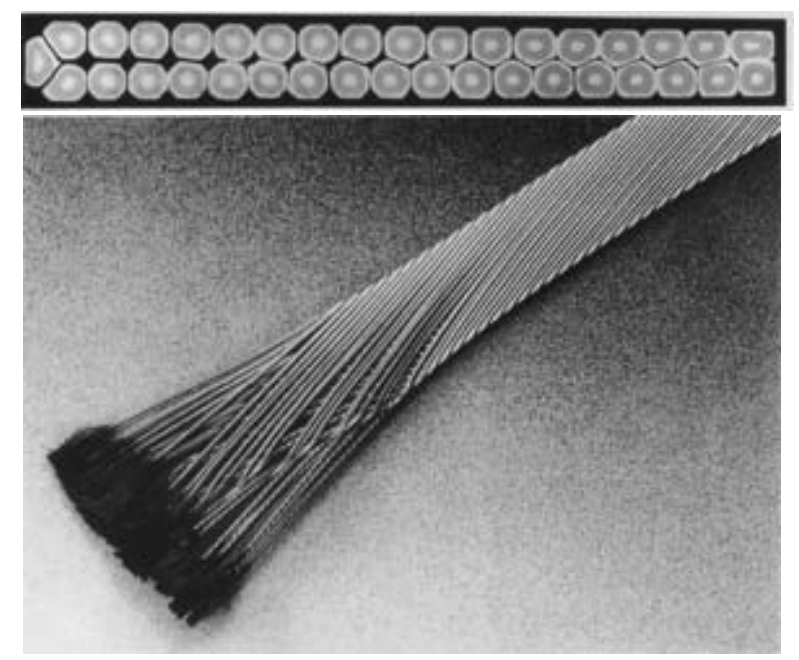

Fig. 3 Rutherford-type Nb-Ti cable for LHC. Width: 15 mm, Thickness: $~ 1.5 \mathrm{~mm}$, No. of elementary wires: $36 .{ }^{4)}$

なる。組成による $\mathrm{T}_{\mathrm{c}}$ と $\mathrm{B}_{\mathrm{c} 2}$ の変化は後述の $\mathrm{Nb}-\mathrm{Zr}$ 系と類似 しているが、 $\mathrm{T}_{\mathrm{c}}$ は $10.8 \mathrm{~K}$ の Nb-Zr 系より若干低い。実用の $\mathrm{Nb}-46.5 \mathrm{wt} \% \mathrm{Ti}$ 線の $\mathrm{B}_{\mathrm{c} 2}(4.2 \mathrm{~K})$ は中点で約 $11.4 \mathrm{~T}$ である ${ }^{7)}$ 。

第二種超伝導体の GLAG（Ginzburg-Landau-Abrikosov） 理論によると、 $\mathrm{B}_{\mathrm{c} 2}$ は $\mathrm{B}_{\mathrm{c} 2}=3.11 \times 10^{3} \cdot \rho_{\mathrm{n}} \cdot \gamma \cdot \mathrm{T}_{\mathrm{c}}$ で与えられる。 ここに $\rho_{\mathrm{n}}$ は正常状態の電気抵抗、 $\gamma$ は電子比熱の温度係 数である。 $\mathrm{Nb}-\mathrm{Ti}$ 系では $\rho_{\mathrm{n}}$ は $\mathrm{Ti}$ 量の増加により直線的に 増加するため、Fig. 5 で $\mathrm{B}_{\mathrm{c} 2}$ が最大になる $\mathrm{Ti}$ 量は $\mathrm{T}_{\mathrm{c}}$ の最大 になる $\mathrm{Ti}$ 量より $\mathrm{Ti}$ 側にシフトする。しかし、 $\mathrm{Ti}$ 側では $\mathrm{T}_{\mathrm{c}}$ が急激に低下寸るため、 $\mathrm{B}_{\mathrm{c} 2}$ と $\mathrm{Ti}$ 量の関係に極大点を生じ るのである。実用合金では $\alpha-\mathrm{Ti}$ が析出すると母相の Ti 量 が減少するため、Fig. 5 の関係から $\mathrm{T}_{\mathrm{c}}$ や $\mathrm{B}_{\mathrm{c} 2}$ が変化する。 一般に $\mathrm{T}_{\mathrm{c}}$ は少し上昇するが、 $\mathrm{B}_{\mathrm{c} 2}$ は $\mathrm{Nb}-\mathrm{Ti}$ 組成により若干

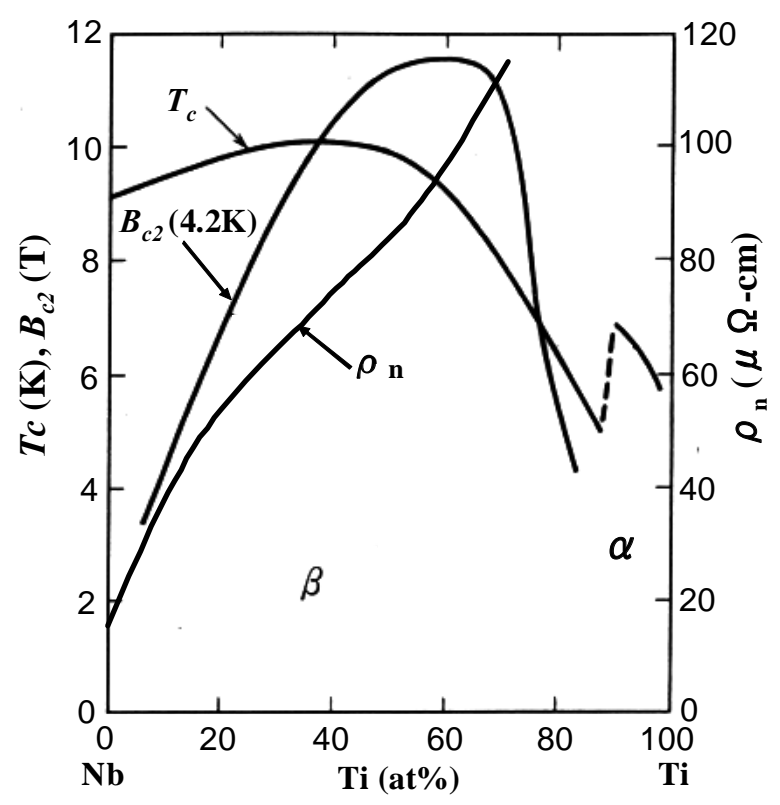

Fig. 5 Variation of $\mathrm{T}_{\mathrm{c}}, \mathrm{B}_{\mathrm{c} 2}(4.2 \mathrm{~K})$ and $\rho_{\mathrm{n}}$ at room temperature with $\mathrm{Ti}$ concentration in $\mathrm{Nb}-\mathrm{Ti}$ alloy. 


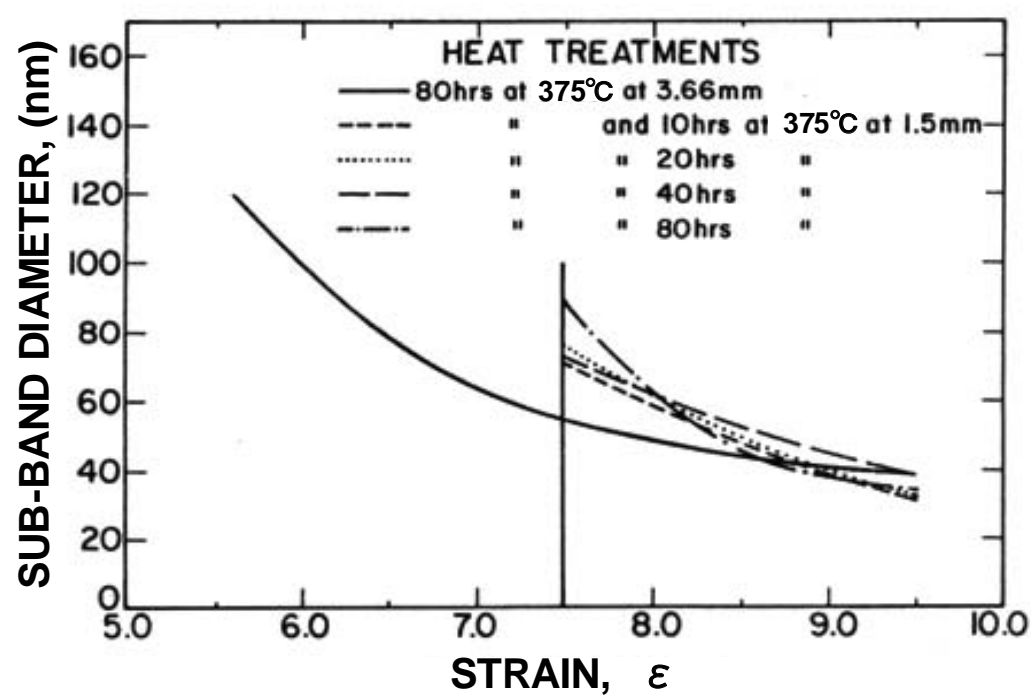

Fig. 6 Plot of the sub-band diameter against the strain for samples with single- and double-heat treatments. ${ }^{8)}$

低下する場合と上昇する場合がある。

実用 Nb-Ti 合金線の組織の詳細については大型の Tevatron 加速器の開発や超電導 MRI 市場の成長に関連して、

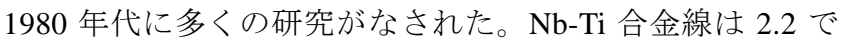
述べたように、極めて大きい減面加工が加えられる。ここ で $A_{0}$ を加工前断面積、 $A$ を加工後断面積として、加わった 歪量 $\varepsilon$ あいは加工量を自然対数表示で $\ln \left(A_{0} / A\right)$ で表すこ とが多い。

このような強度の加工により線材内に高密度の転位網 が導入されてセル構造をとりいわゆるサブバンド組織が 形成される ${ }^{8)}$ 。これらのサブバンドは線引方向に引伸され た組織を示す。また通常線材には加工の途中で，350〜 $400^{\circ} \mathrm{C}$ における複数回の時効熱処理が挿入される。組成が $\mathrm{Nb}$ 側ではサブバンド組織のみであるが、 $\mathrm{Ti}$ 側の実用線材 ではこの熱処理により $\alpha-\mathrm{Ti}$ 析出相が導入される。サブバン

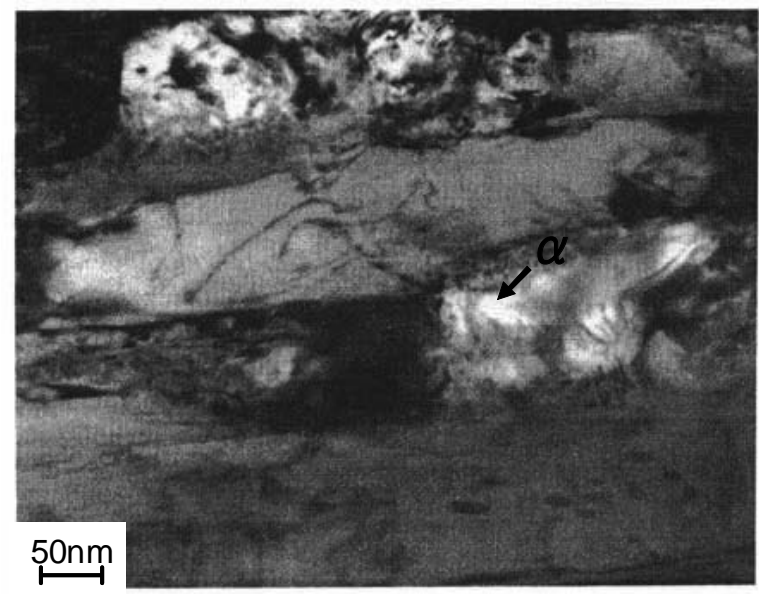

(a)
ドや析出はJ $\mathrm{c} に$ 強く影響するものの Nb-Ti 合金線の組織は 極めて複雑で不均一なため、磁束線のピン止めに対応した 定量的な解析は難しい。実用線材では 2.2 で述べたように、 極めて多数の極細 Nb-Ti 芯が複合されるので、線材では平 均化された」c特性が観測されると考えられる。

文献 ${ }^{8)}$ の組立てビレット外径は $250 \mathrm{~mm}$ で 2,000 本の $\mathrm{Nb}-46.5$ wt\%Ti 芯からなり、 $600^{\circ} \mathrm{C}$ で $63 \mathrm{~mm} \phi$ に押出し後 $0.67 \mathrm{~mm} \phi$ まで線引した。途中 $3.66 \mathrm{~mm} \phi$ と $1.5 \mathrm{~mm} \phi$ で、 $375^{\circ} \mathrm{C}$ で種々の時間中間熱処理を行っている。 Nb-Ti 芯の径 は線径 $0.67 \mathrm{~mm}$ で約 $10 \mu \mathrm{m}$ となる。

Fig. 6 にはこの線材の $\varepsilon$ (加工量) 及び $1.5 \mathrm{~mm} \phi$ での中間 熱処理時間によるサブバンド径の変化を示した。サブバン ド径は初期加工で大きく減少し、また中間熱処理では時間 とともに増大する。さらに熱処理後の再加工でサブバンド 径は再び減少し、0.67 $\mathrm{mm} \phi$ では約 $40 \mathrm{~nm}$ と中間熱処理

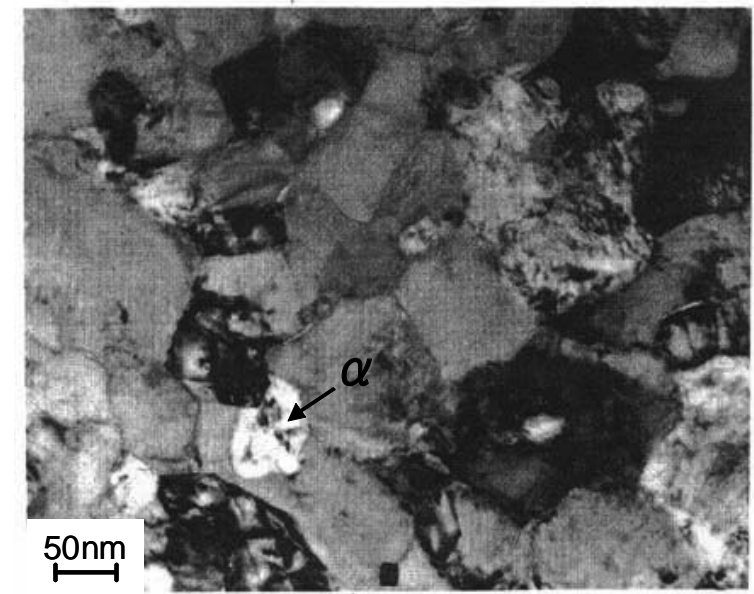

(b)

Fig 7 Transmission electron micrographs of the $1.5 \mathrm{~mm}$-diameter wire heat-treated at $375^{\circ} \mathrm{C}$ for $80 \mathrm{~h}$. (a): longitudinal section, (b): transverse section. ${ }^{8)}$ 
Table2 Planimetry measurements on precipitation of $\alpha$-Ti during thermomechanical processing ${ }^{9)}$

\begin{tabular}{ccccc}
\hline Strain $(\varepsilon)$ & $\begin{array}{c}\text { Filament } \\
\text { diameter }(\mu \mathrm{m})\end{array}$ & Heat treatments & $\begin{array}{c}\text { Vol.\% } \\
\alpha \text {-precipitate }\end{array}$ & $\begin{array}{c}\text { Mean transverse } \\
\text { cross-sectional } \\
\text { area of } \alpha \text { (nm2) }\end{array}$ \\
\hline 6.00 & 1960 & 1 & 9 & 11000 \\
7.16 & 1000 & $1-\mathrm{a}$ & 6 & 4600 \\
7.16 & 1000 & 2 & 8 & 6200 \\
9.5 & 350 & 4 & 17 & 6900 \\
10.72 & 200 & $4-\mathrm{b}$ & 16 & 2600 \\
10.72 & 200 & 5 & 21 & 4800 \\
11.87 & 110 & 6 & 17 & 6000 \\
\hline
\end{tabular}

a: Before 2nd H.T. b: Before 5th H.T.

の影響は殆どみられないことがわかる。

Fig 7 (a),(b)には $1.5 \mathrm{~mm} \phi$ で 80 時間熱処理した線材の長 さ方向及び断面方向の透過電顕写真をそれぞれ示した。長 時間中間熱処理後なので組織が粗大化して見やすくなっ ている。図で白い部分は $\alpha-\mathrm{Ti}$ 相であるとしている ${ }^{8)}$ 。

この $\alpha-\mathrm{Ti}$ 析出相組織の加工と熱処理の繰返しによる変 化については詳しい研究がある ${ }^{9)}$ 。試料は 46.5 wt\%Ti で、 純度の良い高均一度合金を用いている。線材構成は $19 \times 19$ $=361$ 芯で、芯径が $1.96 \mathrm{~mm}$ から $110 \mu \mathrm{m}$ の間に 6 回、 $405^{\circ} \mathrm{C}$ $\times 10 \mathrm{~h}$ の熱処理を挿入したのち、芯径 $13.3 \mu \mathrm{m}$ まで熱処理 なしに線引を行っている。この線材のJ 3,000 A/ $\mathrm{mm}^{2}$ となる。

Table 2 に加工と熱処理による $\alpha$ 相の大きさと体積比が 示されている。 $\alpha$ 相は芯径 $1.96 \mathrm{~mm}$ (それまでに $\varepsilon=6.00$ の加工が施されている）における最初の熱処理で粒界の結 合点に等方的な形状で析出し、線引きにより加工方向に引

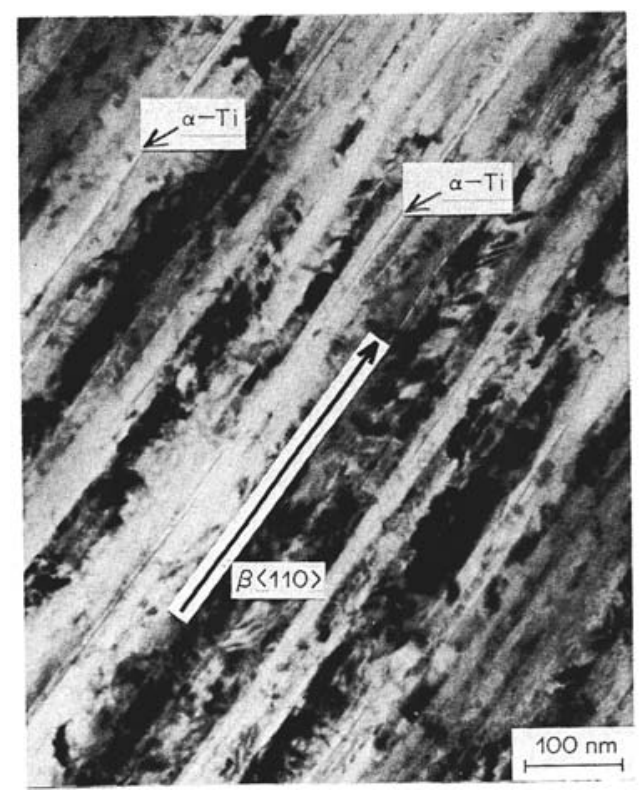

Fig. 8 A TEM image of a longitudinal crosssection of a Nb-Ti filament at $\sim 20 \mu \mathrm{m}$ in diameter. Two representative $\alpha$-Ti are indicated. ${ }^{9)}$
延される。加工後の熱処理により $\alpha$ 相は粗大化するが、線 引と熱処理の繰返しで細かくなり、一方その断面積比は増 加する。しかし、2 回目以後の熱処理では $\alpha$ 相の大きさは ほぼ一定となり、また体積比も 4 回目の熱処理までは増大 するがそれ以後は大きく変わらない。Table 2 の例では $\alpha$ 相 の体積比は最大 $20 \%$ 程度となるが、 $390^{\circ} \mathrm{C}$ で $1,000 \mathrm{~h}$ の極め て長時間の熱処理を加えると $28 \%$ に高められる ${ }^{10) 。}$

6 回目の熱処理後の中間熱処理なしの線引で $\alpha$ 相はアス ペクト比の大きいリボン状に引き延ばされ、芯径 $13.3 \mu \mathrm{m}$ では厚さ約 $1 \mathrm{~nm}$ 、その間隔は約 $4 \mathrm{~nm}$ となる。Fig. 8 は芯径 約 $20 \mu \mathrm{m}$ に線引した場合の加工方向断面の透過電顕写真で ある。 $\alpha$ 相は Fig. 7 の熱処理後と比較して加工方向に薄く 引き延ばされていることがみられる。なお $\beta \mathrm{Nb}-\mathrm{Ti}$ 母相の $<100>$ 結晶軸が加工方向にそろう組織となる。 $\alpha$ 相リボン の長さは 1〜2 $\mu \mathrm{m}$ ののが多く、また線材断面組織では $\alpha$ 相リボンは屈曲しており、その幅は数十 $\mathrm{nm}$ になる。

なお、極細多芯線では、Nb-Ti 芯の径が長さ方向に変動 してくびれを生ずるいわゆるソーセージングを生ずる場 合があり、線材の Jcに悪い影響を与える。これは 2.1 で述 ベた出発素材の $\mathrm{Nb}-\mathrm{Ti}$ 棒表面の不健全部等が原因になる。

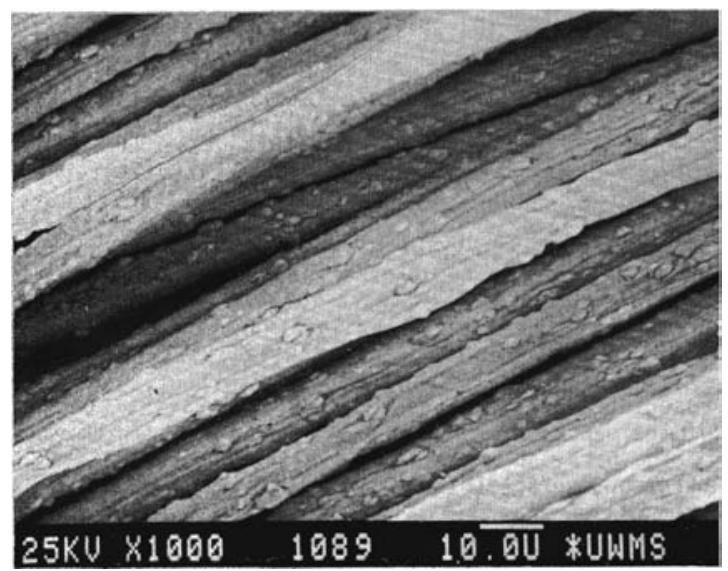

Fig. 9 Scanning electron micrograph of $\mathrm{Nb}-\mathrm{Ti}$ filaments. The small nodules on the filaments are intermetallic compounds. ${ }^{11)}$ 
さらにFig. 9 に示したような芯の表面に小さな瘤が発生

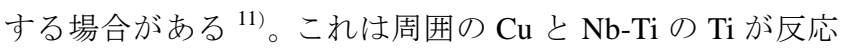
して生じた金属間化合物と考えられ、先に述べた多芯ビレ ットの熱間押出しの際生ずる可能性がある。そのため線材 の加工条件の最適化や、極細芯に加工する場合には Nb-Ti 芯表面に $\mathrm{Cu}$ との反応防止の $\mathrm{Nb}$ バリアをつけることなどに よる対策が図られている。

以上述べたように Nb-Ti 合金線組織は、熱処理やその後 の加工により大きく変化する。そのため極細多芯線とする ことは、前稿 1)でふれた完全安定化のためばかりでなく、 極めて多数の芯を束にすることにより線材特性のばらつ きをなくする上にも有効であると考えられる。

\section{4. 線材の処理による磁界特性の変化}

前節で述べたように Nb-Ti 合金線内には、転位セル（サ ブバンド)、 $\alpha$ 析出相などの磁束線のピン止め点になりう るものが多く存在し、これらの不均質点の形状は熱処理や 加工で大きく変化する。とくに $\alpha$ 析出相は有効なピン止め 点となり、前稿 ${ }^{1)}$ で述べたように Nb-Ti 合金を実用超伝導 線材としてクローズアップする原動力となった。その形状 が熱処理後の球状からその後の加工で帯状となると、点に よるピン止めが面によるピン止めになって有効性を増し、 Jcの増大に大きく寄与すると考えられる。その厚さと間隔 は量子磁束線の径の〜 $10 \mathrm{~nm}$ や $5 \mathrm{~T}$ における間隔の〜20 nm よりかなり小さくなり、複数の $\alpha$ 相リボンがピンニングに 寄与寸ると考えられる。Nb-Ti 合金線における磁束線のピ ンニングについては先の講座 ${ }^{12)}$ 参照されたい。

線材の処理による J $\mathrm{c}$-磁界特性の変化の一例として、 Nb-61.7 at\%Ti-3.0 at\%Hf 多芯線材について報告されている 熱処理及び加工による特性変化について述べる ${ }^{13)}$ 。試料は $21 \mu \mathrm{m} \phi$ の 295 本の芯からなり、線径は 0.55 mm である。 線材の J $\mathrm{c}$ は冷間加工 (CW)、熱処理 $(\mathrm{HT})$ 及び両者の組 合せ $(\mathrm{HT}+\mathrm{CW})$ により大きく変化する。Fig 10 には CW 線材、HT（350 $\mathrm{C} \times 72 \mathrm{~h} ）$ 線材及び $\mathrm{HT}+\mathrm{CW}$ 線材における ピン止め力 $\mathrm{F}_{\mathrm{p}}$ と磁界の関係を示した。

$\mathrm{CW}$ 線材の $\mathrm{F}_{\mathrm{p}}\left(\mathrm{J}_{\mathrm{c}} \times\right.$ 磁界のベクトル積 $)$ のピークは高磁 界側にあり、熱処理した HT 線材では著しく低磁界側にシ フトするが、最大のピン止め力 $\mathrm{F}_{\mathrm{p}(\max )}$ は $\mathrm{CW}$ 線材の約 4 倍 となる。しかし $4.2 \mathrm{~K} 、 8 \mathrm{~T}$ 以上におけるピン止め力はむし ろ減少している。熱処理後再度加工を行った $\mathrm{HT}+\mathrm{CW}$ 線材 では、ピークは高さを増してその位置が $\mathrm{B}_{\mathrm{c} 2}$ の約 $1 / 2$ の磁界 一移る。 $\mathrm{F}_{\mathrm{p}(\max )}$ は $\mathrm{HT}$ 材の $1.5 \sim 2$ 倍となり、また温度を 1.8 $\mathrm{K}$ に下げると各処理材とも $\mathrm{F}_{\mathrm{p}(\max )}$ は、 $4.2 \mathrm{~K}$ の值の $1.5 \sim 2$ 倍になることがわかる。Hf 置換線材では温度の低下による 高磁界特性の改善が 2 元系線材より大きくなる。

このように熱処理によって $\alpha$ 析出相が導入されると J c が向上して $F_{\mathrm{p}}$ が著しく増大する。また再加工により $\mathrm{F}_{\mathrm{p}}$ が さらに増大寸るとともにピーク位置が高磁界側にシフト

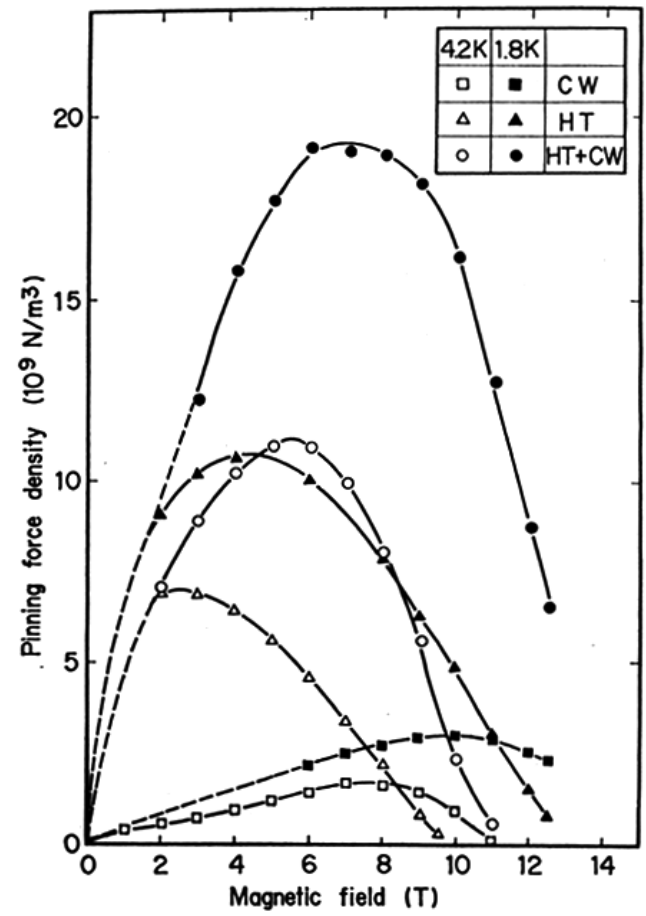

Fig 10 Flux-pinning force $F_{p}$ at $4.2 \mathrm{~K}$ and $1.8 \mathrm{~K}$ versus the magnetic-field curves for $\mathrm{Nb}-\mathrm{Ti}-\mathrm{Hf}$ wire after the quoted treatment. ${ }^{13)}$

する。このシフトは前節で述べたように加工により組織が 微細化し、磁束格子構造とのマッチングが高磁界側で改善 されるためであろう。Fig. 10 の結果から、 $F_{p}\left(J_{c}\right)$ の向上に は $\alpha$ 析出相の方が $8 \mathrm{~T}$ 以下では加工で導入されるサブバン ドより有効であることがわかる。

中間焼鈍は通常 350〜 $400^{\circ} \mathrm{C}$ で行われる。しかし 8〜10 T の高磁界側の J $\mathrm{c}$ に対しては $450 \sim 475^{\circ} \mathrm{C}$ の高温よりの熱処 理が有効なことが報告されている ${ }^{13)}$ 。これは高温よりの熱 処理によってこの線材の $\mathrm{B}_{\mathrm{c} 2}$ が高められるためと考えられ る。一方、中間熱処理後の加工では加工度ともにJ $\mathrm{c}$ が高め られる。しかし過度の加工で却って低下することが報告さ れている ${ }^{13)}$ 。先に述べた $\alpha$ 相の体積比 $28 \%$ の線材でも」c $(4.2 \mathrm{~K}, 5 \mathrm{~T})$ は $\varepsilon=4.6$ の加工で $4,000 \mathrm{~A} / \mathrm{mm}^{2}$ の最大值を示 し、それ以上の加工で低下する ${ }^{10)}$ 。

$\mathrm{Nb}-\mathrm{Ti}$ 合金線の組織における圧延による形状異方性の影 響についても研究がなされている。圧延テープでは磁界を テープ面に平行に加えると、垂直に加えた時よりJ゙が格段 に高くなり $4.2 \mathrm{~K} 、 5 \mathrm{~T}$ で 6,000 A $/ \mathrm{mm}^{2}$ に達する。これは組 織が層状となり、ピン止め点の密度に両方向で大きい差が 出来るためと考えられる ${ }^{10)}$ 。

一方、筆者らは Nb-Ti 合金線の加工により $\mathrm{B}_{\mathrm{c} 2}$ に異方性 を生じ、熱処理により消失することを見出した ${ }^{7)}$ 。Fig 11 には Nb-62.8 at\%Ti 合金線（NIST-SRM 1457 線）の $4.2 \mathrm{~K} の$ $\mathrm{B}_{\mathrm{c} 2}$ の印加磁界の角度による变化を示した。磁界が線材加工 方向（平行方向）に近づくに従い $\mathrm{B}_{\mathrm{c} 2}$ が高くなり、また遷 移がシャープになる。平行方向では $\mathrm{B}_{\mathrm{c} 2}$ の中点は $12.5 \mathrm{~T}$ と 垂直方向より $1 \mathrm{~T}$ 以上高くなる。 


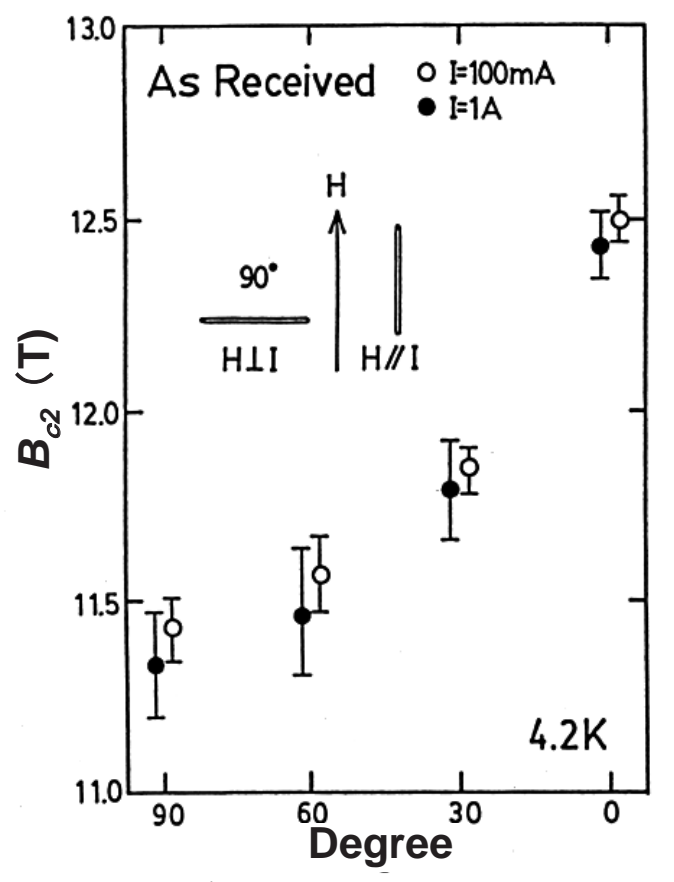

Fig. $11 B_{c 2}(4.2 \mathrm{~K})$ of NIST-SRM1457 wire versus the angle of the applied magnetic field. ${ }^{7)}$

Fig. 12 には $\mathrm{B}_{\mathrm{c} 2}$ （中点）の異方性の焼鈍温度による变化 と $500^{\circ} \mathrm{C}$ 焼鈍後の再加工による変化を示した。 $\mathrm{B}_{\mathrm{c} 2}$ は焼鈍に より低下し、また熱処理温度が高まるにつれて上記の異方 性が消失することがわかる。再加工では $\mathrm{B}_{\mathrm{c} 2}$ が高められる とともに異方性が再び現れる。このような結果は、加工に よって $\mathrm{B}_{\mathrm{c} 2}$ を高める因子が導入されること、また処理と微 細組織の研究によって $\mathrm{B}_{\mathrm{c} 2}$ 、従って高磁界特性が改善され る余地があることを示すものであろう。

また、Nb-Ti をベースとした 3 元合金の研究も多く行わ れたが、大きい特性の改善は得られていない。Ta または $\mathrm{Hf}$ の添加で $\mathrm{B}_{\mathrm{c} 2}$ に $4.2 \mathrm{~K}$ で $0.2 \mathrm{~T}$ 程度、 $2 \mathrm{~K}$ で $1 \mathrm{~T}$ 程度の向 上が得られている。本節で述べたように Nb-Ti 合金では熱 処理と加工条件の調整により線材を使用する磁界に対応 して最高の $J_{\mathrm{c}}\left(\mathrm{F}_{\mathrm{p}}\right)$ を得ることが出来る点好都合である。線 材の製造部門ではすでに熱処理と加工の組合せの最適化 が図られているものの、この点は材料研究者にとり大きな 興味の対象となる。

\section{5. 人エピン導入線材、交流用線材及び AI 安定化} 線材

\section{1 人エピン導入線材}

$\mathrm{Nb}-\mathrm{Ti}$ 合金線材の場合 $\alpha$ 析出相のリボンが有効なピン止 め点となるが、前節で述べたように線材断面ではランダム に屈曲して均一ではない。線材の Jcは局所的な Jcの最小值 で限定されるので、 $\alpha$ 析出相の代りに加工性の良いピン止 め材を規則的に組み込んでその体積分率や形状を制御し てより有効なピン止め点を導入する試みがなされた ${ }^{14)}$ 。

人工ピン止め点の材質としては $\mathrm{Nb} 、 \mathrm{Cu} 、 \mathrm{Ni}$ 等が試みら

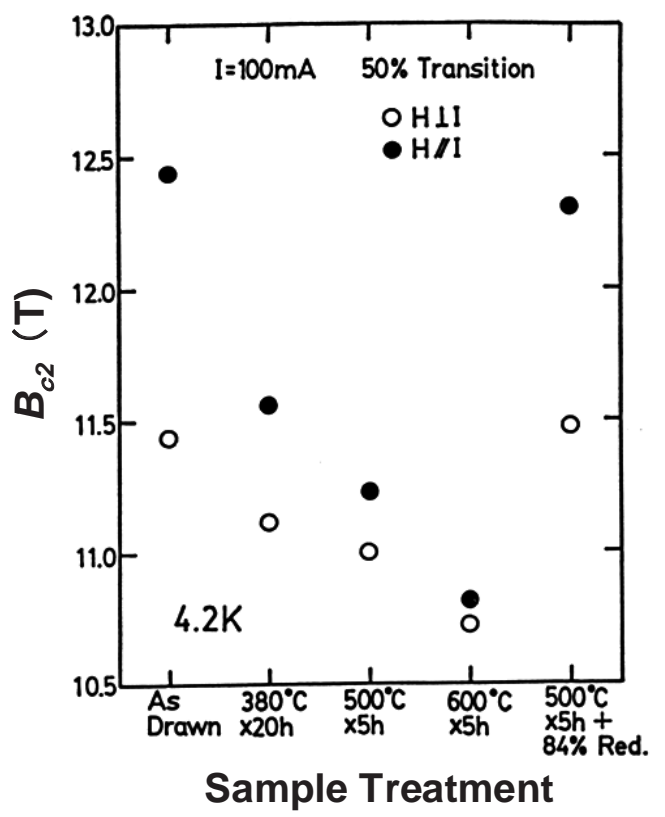

Fig 12 Effect of the heat-treatment temperature on the anisotropy in $B_{c 2}$ (mid) of the wire shown in Fig. 11. The $\mathrm{B}_{\mathrm{c} 2}$ (mid) of wire heat-treated at $500^{\circ} \mathrm{C}$ followed by an $84 \%$ reduction in area is also shown.

れており、その配置はラメラ型やアイランド型などがある。 Fig. 13 に Nb を用いたラメラ型人ロピン導入 Nb-Ti 合金線 材の断面組織を示した ${ }^{15)}$ 。線材の作製法は $\mathrm{Cu}$ 管に Nb-50wt\% Ti 板と Nb 板を交互に重水て挿入し、熱閒押出し と伸線により素線とし、外側の $\mathrm{Cu}$ をとり除いたのちその 多数本を再び $\mathrm{Cu}$ 管に挿入して 6 角線に加工する。これを 再び多数本 $\mathrm{Cu}$ 管につめて最終ビレットとして線材に加工 したものである。

Fig. 13 で白い部分が Nb で、Nb は線材長手方向に連続し た 2 次元のピン止め点となる。Jcと $\mathrm{Nb}$ 層の厚さの関係で

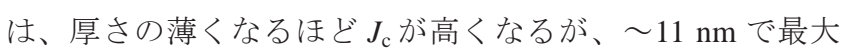
となりそれ以下では低下する。得られたJ $4,250 \mathrm{~A} / \mathrm{mm}^{2}$ で、 $\alpha$ 相析出型 $\mathrm{Nb}-\mathrm{Ti}$ 線材をしのぐ值が得られ

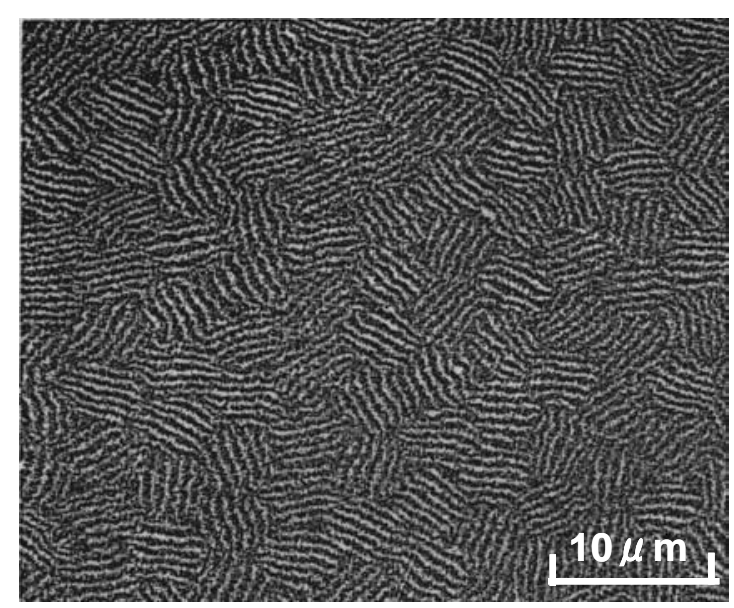

Fig 13 Lamelae-type $\mathrm{Nb}-\mathrm{Ti} / \mathrm{Nb}$ artificial pinning centers. ${ }^{15)}$ 


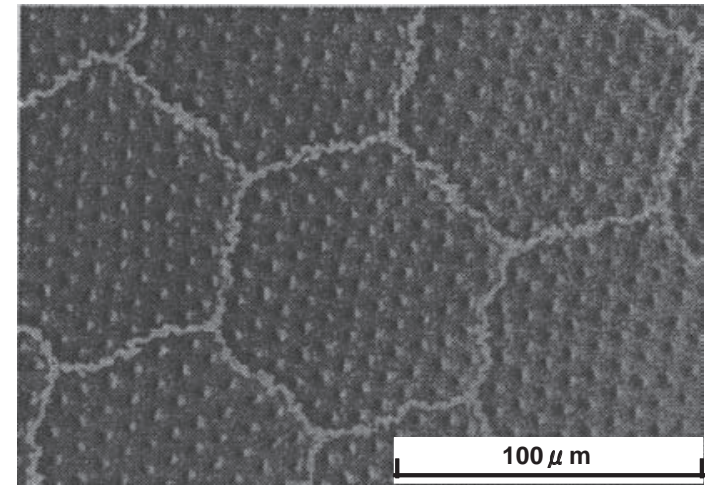

Fig. 14 Island-type $\mathrm{Ni} / \mathrm{Cu}$ pinning centers introduced in $\mathrm{Nb}$-Ti wire. ${ }^{16)}$

た。しかしその $\mathrm{B}_{\mathrm{c} 2}(4.2 \mathrm{~K})$ は $\mathrm{Nb}$ 層厚が薄くなるとともに 近接効果により低下し、〜11 nm 厚さでは約 $9.2 \mathrm{~T}$ となる ${ }^{15)}$ 。

一方 $\mathrm{Ni}$ のような強磁性粒子はより有力なピン止め点と なると考えられ、Nb-47 wt\%Ti 合金線に Ni を組み込んだ線 材が研究された ${ }^{16)}$ 。 $8 \mathrm{vol} \%$ の $\mathrm{Ni}$ の周りに $4 \mathrm{vol} \%$ の $\mathrm{Cu}$ バリ アをつけたもの及び比較のため $12 \mathrm{vol} \%$ の $\mathrm{Cu}$ のを導入し た試料を作製した。線材は Nb-Ti 合金にガンドリルで孔を あけて上記の棒を挿入して線引した単芯線から出発した。 これを 91 本複合して周りを $\mathrm{Nb}$ バリアで包んだ後 61 本複 合した 2 次ビレットを細線に線引した。Fig 14 に加工途中 の線材断面を示したが、91 本のピン止め点がアイランド型 にきれいに配置されている。最終加工後のピン止め点の径 は $10 \mathrm{~nm}$ 程度になる。

$\mathrm{Ni}$ の周りの $\mathrm{Cu}$ 層の厚さは 1 ～ $3 \mathrm{~nm}$ であるが、近接効果 の軽減のため高抵抗の $\mathrm{Cu}-\mathrm{Ni}$ 層に変えるため 5 分程度の低

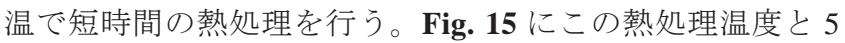

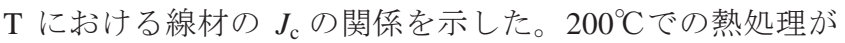
最適であり、4.2 K、5 T で約 5,100 A/ $\mathrm{mm}^{2}$ の極めて高いJc が得られた。また図から Cu をピン止め点とした線材の約 $3,000 \mathrm{~A} / \mathrm{mm}^{2}$ に比べて 1.7 倍の大きさとなる。この $\mathrm{Ni}$ をピ ン止め点とした線材の $4.2 \mathrm{~K}$ における $\mathrm{B}_{\mathrm{c} 2}$ は約 $11 \mathrm{~T}$ で殆ど 低下がなく、Ni の導入は前述した $\mathrm{Nb}$ や $\mathrm{Cu}$ の導入より好 ましい結果が得られた。

$\mathrm{Nb}-\mathrm{Ti}$ 合金線への人工ピンの導入は有効なことが証明さ れ、また $\alpha-\mathrm{Ti}$ 析出相制御のための加工/熱処理のプロセス の最適化を考慮する必要がない。人工ピンの導入は研究的 な関心から着手されたが、企業でも試作を行い、また Nb-Ti より $\mathrm{T}_{\mathrm{c}}$ の高い Nb-Zr 合金（後述）への導入も研究されてい る。しかしその線材作製には手間を必要とするため、本格 的に市場化されるには至っていない。

\section{2 交流用線材}

交流損失の小さいNb-Ti合金線材の研究開発は1980年代 から開発され、とくにわが国及びフランスで熱心に研究さ れた。最近も速い励磁を伴う加速器や核融合装置で求めら れ、またわが国では超電導発電機（Super-GM）プロジェク トに関連して開発が行われた。超電導交流機器では、冷媒

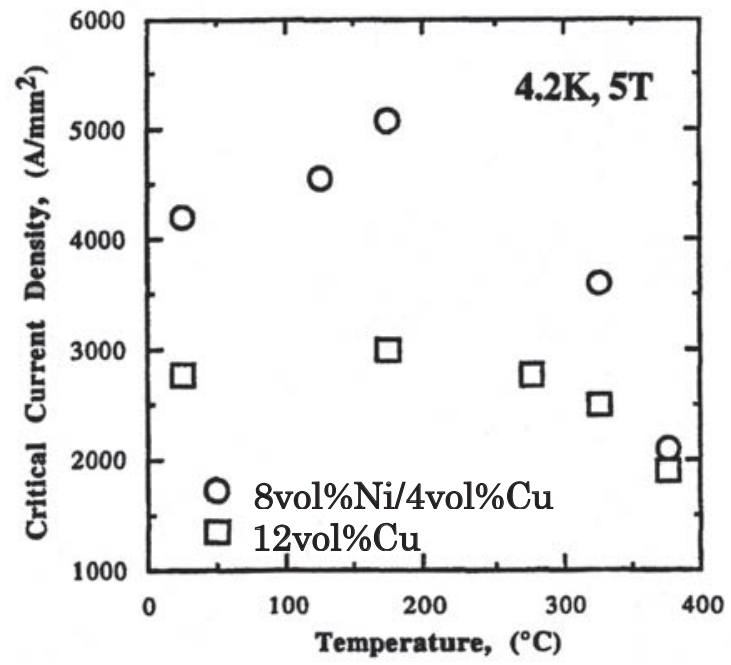

Fig. $15 \mathrm{~J}_{\mathrm{c}}$ of a Nb-Ti wire with 8 vol\% Ni/ 4 vol\% $\mathrm{Cu}$ and 12 vol\% $\mathrm{Cu}$ pinning centers at $4.2 \mathrm{~K}$ and $5 \mathrm{~T}$ versus the final heat-treatment temperature. ${ }^{16)}$

の液化電力まで含めたトータルの損失が $\mathrm{Cu}$ 線を用いた常 電導機器損失より小さいことが望まれる。超電導線材の交 流損失の詳細に関しては例えば文献 ${ }^{17)}$ がある。超電導線材 を交流で使用すると、ヒステリシス損失、結合損失などが 伴われる。

先に述べたように超電導線材で大きい」cを得るためには 強いピンニングが必要で、そのため大きい磁化履歴を生じ て交流使用の際にヒステリシス損失が生まれる。すなわち ピンニングは大きい小 $\mathrm{c}$ をもちす一方交流損失の原因とな る。ヒステリシス損失 $W_{\mathrm{h}}$ は $\mathrm{J}_{\mathrm{c}}$ 、フィラメント径 $\mathrm{d}_{\mathrm{f}}$ 、使用 磁界及び交流周波数に比例して増大寸る。これらの内で線 材の一定使用条件の下で $W_{\mathrm{h}}$ を小さく出来る因子としては $\mathrm{d}_{\mathrm{f}}$ の減少がある。従って交流用線材はフィラメント径をサ ブミクロンまで小さくし、さらに線材に必要な $\mathrm{I}_{\mathrm{c}}$ をたせ るため極めて多数の芯が組み込まれた超極細多芯線となる。

一方、フィラメントのカップリングで生じる結合電流に よるマトリックス内のジュール損失 $\mathrm{W}_{\mathrm{c}}$ を小さくするには 線材をツイストして結合電流を分断することが有効で、 $\mathrm{W}_{\mathrm{c}}$ はツイストピッチ及び使用磁界の 2 乗に比例する。また $\mathrm{W}_{\mathrm{c}}$ と $\mathrm{Cu}$ ジャケット内の渦電流損失を小さくするにはマト リックスの高抵抗化と $\mathrm{Cu}$ ジャケットを高抵抗バリアで細 かく分割することが有効である。

実際の交流用素線は $0.1 \sim 0.5 \mu \mathrm{m} \phi$ の超極細フィラメン トが高抵抗のマトリックスに数十万本埋込まれ、ツイスト ピッチを小さくするため素線径は $0.1 \sim 0.5 \mathrm{~mm}$ まで線引さ れる。通常最短のツイストピッチは素線径の 4 倍が限界と されている。また、線材の $\mathrm{I}_{\mathrm{c}}$ を増すため、例えば素線を 6 本よりしたものをさらに 6 本よりした多重のケーブルとし て用いられる。Cu-10 wt\%Ni や 30 wt\%Ni 合金がマトリクス と上記の 6 本より線の中央の芯として使われている。ケー ブルでは素線間の結合防止も必要となる。10 wt \% Ni 合金と 


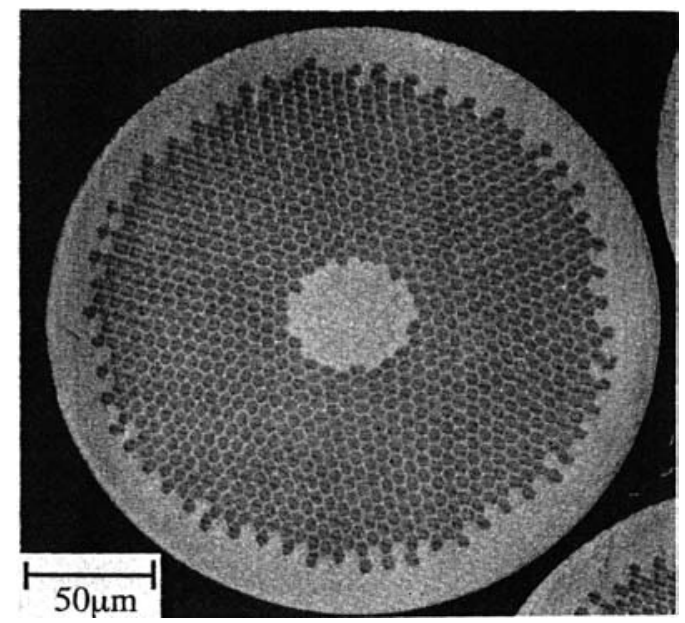

Fig 16 Cross-section of an ac wire (strand) containing $\sim 10^{6}$ fine filaments. ${ }^{18)}$

$30 \mathrm{wt} \% \mathrm{Ni}$ 合金では、前者の方が加工性が良いが、後者の方 がより高抵抗でフィラメント間の結合を抑制するにはさ らに有効である。

交流用線材の一例として Fig $\mathbf{1 6}$ に Super-GMプロジェク トで開発した線材の断面写真を示した ${ }^{18)} 00.25 \mathrm{~mm} \phi$ の素 線にはスタックを繰り返して $0.1 \mu \mathrm{m} \phi$ のフィラメントが 1,023,033 本組み込まれている。マトリックスには Cu-30 $w t \% N i$ 合金が用いられ、中央部と周辺部に $\mathrm{Cu}-10 \mathrm{wt} \% \mathrm{Ni}$ 合 金と $\mathrm{Cu}$ が配されている。

Fig. 17 にこと類似の線材における $\mathrm{d}_{\mathrm{f}}$ と $\mathrm{W}_{\mathrm{h}}$ の関係を示 した ${ }^{18)}$ 。図の Type-1 と 2 の素線には 930,030 本の Nb-Ti フ イラメントが組み込まれているが、Type-1 は Cu-30 wt\% Ni マトリックス、Type-2 は Cu-30 wt\%Ni-0.9 wt\%Mn マトリッ クスが用いられている。 $\mathrm{W}_{\mathrm{h}}$ は先に述べたように $\mathrm{d}_{\mathrm{f}}$ の現象 とともに低下寸る。 $\mathrm{d}_{\mathrm{f}}$ が小さくなりすぎると却って $\mathrm{W}_{\mathrm{h}}$ が 増すのは近接効果のためである。Fig. 17 から Cu-30 wt\%Ni 合金に微量の Mn を添加すると $\mathrm{W}_{\mathrm{h}}$ が 1 桁低下し、 $\mathrm{d}_{\mathrm{f}}=0.1 \mu \mathrm{m}$ で $17 \mathrm{~J} / \mathrm{m}^{3}$ ( $\pm 0.5 \mathrm{~T}$ サイクル)の低い $\mathrm{W}_{\mathrm{h}}$ が達成されている。 これは Mnの磁気モーメントの効果と考えられている。

$\mathrm{Cu}-\mathrm{Ni}$ 合金以外のマトリックス材としては、より安価な $\mathrm{Cu}-\mathrm{Si}$ 合金が研究された ${ }^{19)}$ 。熱処理で高抵抗の薄い Si 層が フィラメント界面に集まるため興味をもたれ、後に小型交 流マグネットも試作され運転されたが、Cu-Si 合金は Cu-Ni 合金より加工性が若干劣る問題点があった。

なおフィラメントの極めて細い交流用線材ではフィラ メント損傷をさけるため、通常 2.3 で述べた $\alpha-\mathrm{Ti}$ 相析出の 熱処理は行わない。フィラメントの表面は有効なピン止め 点となるが、 $\alpha-\mathrm{Ti}$ リボンに比べて間隔が広いため低磁界の J c しか高めない。また素線に Nb-Ti フィラメントを密に配 置しすぎると互いに結合して交流損失が大きくなる。フィ ラメントの閒隔を保って大きい線材 $\mathrm{I}_{\mathrm{c}}$ を得るためにはフィ ラメント自体の J $\mathrm{c}$ を改善することが必要になる。そのため アイランド型の $\mathrm{Nb}$ 人工ピンを配置した Nb-Ti 交流用線材

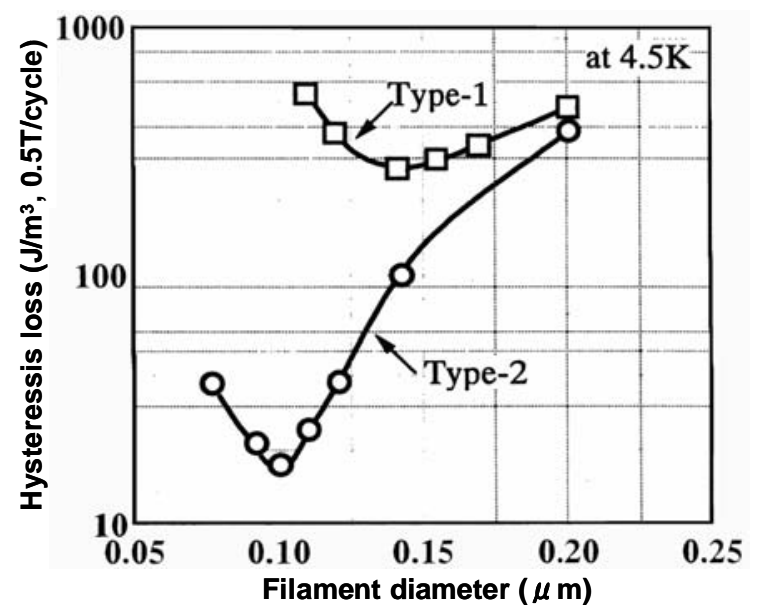

Fig 17 Hysterisis loss ( 0.5 T/cycle) versus the filament diameter. Type- 1 and Type- 2 wires use $\mathrm{Cu}-30$ wt\% $\mathrm{Ni}$ and $\mathrm{Cu}-30$ wt\% Ni-0.9 wt\% Mn matrix, respectively. ${ }^{18)}$

の研究開発がなされ成果を上げている ${ }^{20)}$ 。

本節で述べた交流用 Nb-Ti 線材は小型マグネットにまか れて $50 \mathrm{~Hz}$ の試験運転が多く行われ、また電磁擋拌への応 用も研究されており ${ }^{21)}$ 、今後新たな利用が期待される。な お、2.2 で述べた加速器用の Rutherford ケーブルや LHD (Large Helical Device) 等の核融合装置用導体の交流特性に ついては文献 ${ }^{22)}$ 等の解説があるので参照されたい。

\section{3 Al 安定化線材}

純 $\mathrm{Al}$ は磁気抵抗が $1 \mathrm{~T}$ で飽和するため、より高磁界では $\mathrm{Cu}$ より電気抵抗が小さくなること、低比熱で熱伝導度の高 いことなどのため、Cu に優る安定化材として注目されてい た。また、Cuに比べ軽量なことや誘導放射能特性でも有利 な長所をもつ。しかし強度が小さいため Nb-Ti との複合加 工が難しいことやマグネットに巻いた時の電磁力に対す る耐力が問題とされていた。わが国では近年 $\mathrm{Al}$ 安定化 Nb-Ti 線を用いた大型マグネットが作製され、運転されて いるのでその概要を述べる。

わが国におけるプラズマ科学研究の中心として長期に わたり稼動し成果を上げている LHD 装置にも $\mathrm{Al}$ 安定化 $\mathrm{Nb}-\mathrm{Ti}$ 線が用いられている。Fig $\mathbf{1 8}$ に示すように導体外周 に $\mathrm{Cu}$ シースを設け、内部に 15 本の $\mathrm{Nb}-\mathrm{Ti} / \mathrm{Cu}$ 素線と純度 5 $\mathrm{N}$ の Al 安定化材をいれてはんだで接合されている ${ }^{23)}$ 。 Al と $\mathrm{Cu}$ を直接接合するとホール電流が発生して損失を生じ ることが見出されたため、 $\mathrm{Al}$ に $\mathrm{Cu}-2 \mathrm{wt} \% \mathrm{Ni}$ 層を被覆する 工夫がなされている。さらに $\mathrm{Cu}$ シースのふたは電子ビー

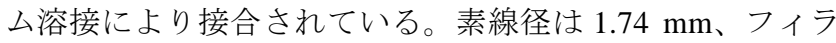
メント径は $47 \mu \mathrm{m}$ 、フィラメント数は 726 で、 $4.4 \mathrm{~K} 、 7 \mathrm{~T}$ で 1,360 A/mm²のJcをもつ。Fig. 10 の導体は $7 \mathrm{~T}$ で約 $50 \mathrm{kA}$ の $\mathrm{I}_{\mathrm{c}}$ を示し、その単長はへリカルコイル各層に応じて 600 〜1,100 m で、全長は $36 \mathrm{~km}$ に達する。

次に 2.2 でふれた LHC 装置の ATLAS 測定用マグネット 


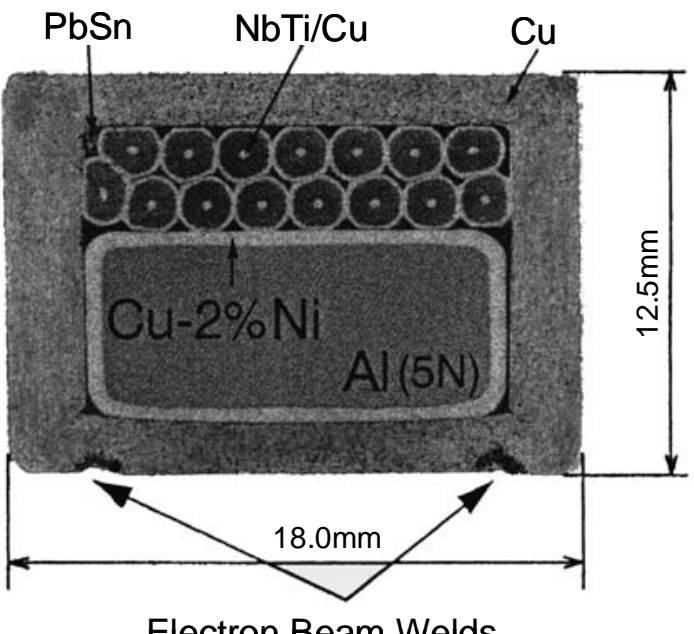

Electron Beam Welds

Fig 18 Cross-section of the Al-stabilized $\mathrm{Nb}-\mathrm{Ti}$ conductor used for the LHD helical coils.

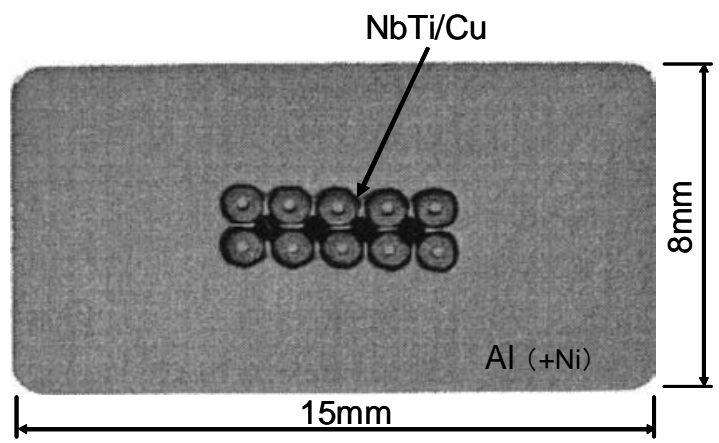

Fig 19 Cross-section of the Al-stabilized Nb-Ti wire used in the RIKEN cyclotron. ${ }^{25}$

に使用された Al 安定化 Nb-Ti 導体を紹介する。ATLAS で は $2.3 \mathrm{~m}$ の常温変間に $2 \mathrm{~T}$ の磁界を発生する長さ $6 \mathrm{~m}$ の薄 肉のマグネットを用い、14 $\mathrm{TeV}$ の陽子-陽子反応で発生し た荷電粒子の運動量を測定する ${ }^{24)}$ 。導体は $4.25 \times 30 \mathrm{~mm}$ の $\mathrm{Al}$ 板に径 $1.25 \mathrm{~mm}$ の $\mathrm{Nb}-\mathrm{Ti}$ 粒子が 12 本 Rutherford より線 として埋め込まれており、 $\mathrm{Nb}-\mathrm{Ti}$ 、周りの $\mathrm{Cu}$ ジャケット及 び Al 安定化マトリックスの面積比は約 1/0.9/15 となる。こ の導体は $4.2 \mathrm{~K} 、 5 \mathrm{~T}$ で約 $2.3 \mathrm{kA}$ の $\mathrm{c}$ をもつ。

上述の $\mathrm{Al}$ マトリックスは $5 \mathrm{~N}$ の純度をもち、1,000 ppm の $\mathrm{Ni}$ が添加されている。 $\mathrm{Ni}$ は $\mathrm{Al}$ に固溶せず粒界に $\mathrm{Al}_{3} \mathrm{Ni}$ 化合物として存在するため、 $\mathrm{Al}$ の高い伝導度を保ったまま 強度を 3 倍以上に高める。その降伏応力は $110 \mathrm{MPa}$ で、抵 抗比 RRR は約 600 である。ATLAS マグネットは欧州合同 原子核機関（CERN）において国際的に大きな貢献をして いる。

同様な $\mathrm{Al}$ 安定化 $\mathrm{Nb}-\mathrm{Ti}$ 線材は理化学研究所の世界初の超 電導リングサイクロトロンのマグネットにも使用された 25)。導体は ATLAS のものに類似しているが、 $8 \times 15 \mathrm{~mm}$ の $\mathrm{Al}$ 合金中に 10 本の Nb-Ti 素線が Rutherford より線として 埋め込まれている。その写真を Fig 19に示したが、この複
合体は Fig.18 の場合と異なり、適当な条件での押出加工に よって成型される。

さらに宇宙線反粒子探査のため南極の高度 $37 \mathrm{~km}$ に昇る Bess-Polar 気球に搭載されているスペクトロメーター用の 超電導マグネットにも $\mathrm{Al}$ 安定化 $\mathrm{Nb}-\mathrm{Ti}$ 線が用いられた ${ }^{26)}$ 。 コイルは直径 $0.9 \mathrm{~m}$ 、長さ $1.9 \mathrm{~m}$ 、中心磁界 $0.8 \mathrm{~T}$ で、厚さ $3.4 \mathrm{~mm}$ の超薄型であり、重量は $40 \mathrm{~kg}$ である。このような 用途には $\mathrm{Al}$ を用いて軽量化されたメリットが大きい。

$\mathrm{Al}$ 安定化超電導線は古くから関心をもたれたが、わが国 では高エネルギー加速器研究機構を中心とした関係各位 の努力により本節で述べたような種々の先端装置で実績 を上げている。 $\mathrm{Nb}-\mathrm{Ti} / \mathrm{Cu}$ 素線をさらに $\mathrm{Al}$ マトリックスに 複合する手間は要するが、今後 $\mathrm{Al}$ 安定化材の進歩等によ りさらなる発展が期待される。

\section{6. その他の合金線材}

Nb-Zr 合金線材は Nb-Ti 合金より高い $10.8 \mathrm{~K} の \mathrm{~T}_{\mathrm{c}}$ と Nb-Ti に近い $10.5 \mathrm{~T}$ の $\mathrm{B}_{\mathrm{c} 2}(4.2 \mathrm{~K})$ をもち、1960 年代前半に関心 をもたれた。しかし Cu との複合による極細多芯線の加工 が容易な Nb-Ti 合金線が開発されてからは研究開発の対象 外になった。Nb-Zr 系の状態図を Fig. 20 に示したが 27)、約 20〜90 wt\%Zr の組成では、約 $600 \sim 900^{\circ} \mathrm{C}$ の間の $\beta$ (bcc 相) $\rightarrow \beta_{\mathrm{Nb}}+\beta_{\mathrm{Zr}}$ の 2 相分離と、それ以下の温度における $\beta_{\mathrm{Nb}}+$ $\alpha_{\mathrm{Zr}}$ (hcp 相) の共析分離の 2 つの相分離があるのが特徵であ る。 $\mathrm{T}_{\mathrm{c}}$ は約 $25 \mathrm{at} \% \mathrm{Zr}$ で最大值をとり、熱処理による変化は 状態図における相変化と対応して理解される ${ }^{28)}$ 。

$\mathrm{Nb}-\mathrm{Zr}$ 合金線の実験室的な加工法については文献 ${ }^{29)}$ があ る。小型のアーク溶解で均一な組成のボタンを溶製し、こ れを舟型るつぼに並べて電子ビーム溶解により棒状イン ゴットとした。これを整形後、溝ロール圧延と線引により $0.25 \mathrm{~mm} \phi$ 、長さ $800 \mathrm{~m}$ の線材に加工した。Cu 被覆のない $\mathrm{Nb}$ 系合金の線引には、グラファイトや $\mathrm{MoS}_{2}$ の固体潤滑剂

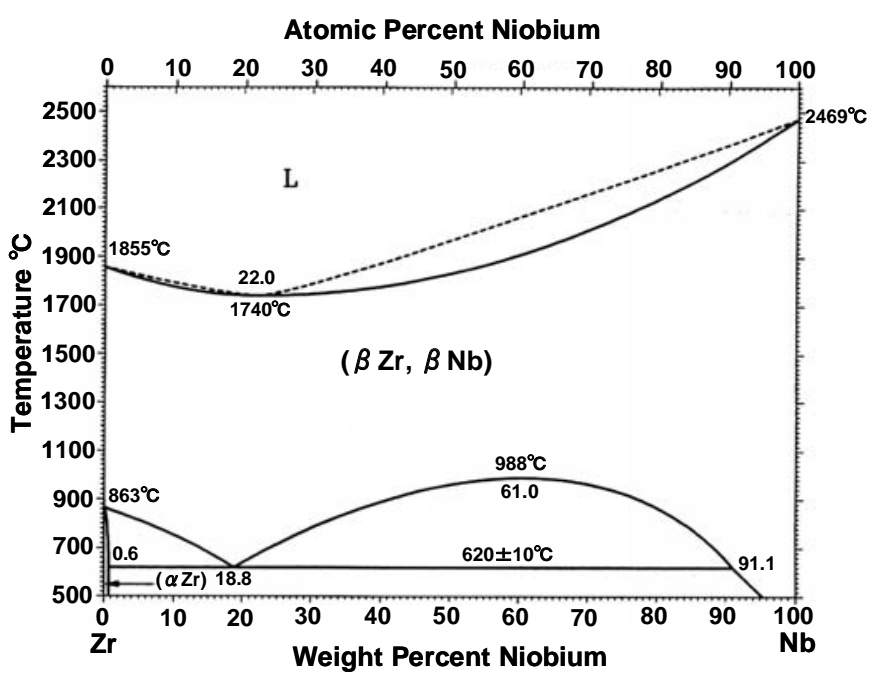

Fig 20 Nb-Zr phase diagram. ${ }^{27)}$ 
(a)

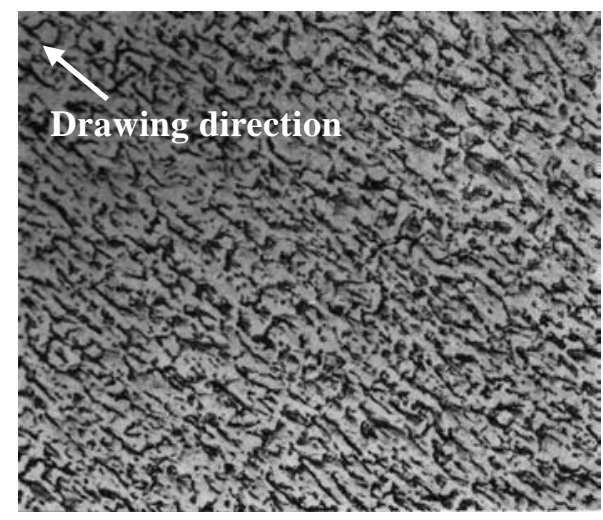

(b)

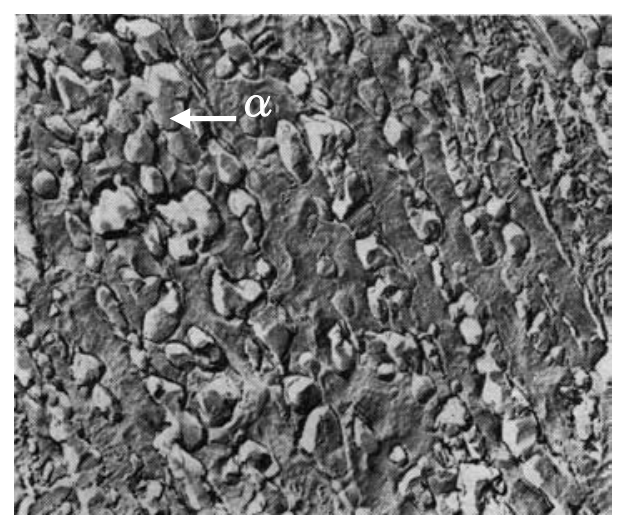

Fig. 21 Electron micrographs of a longitudinal cross-section of $\mathrm{Nb}-53 \mathrm{wt} \% \mathrm{Zr}$ wire fabricated from $6.0 \mathrm{~mm}$ to $1.0 \mathrm{~mm}$ in diameter, and then heat-treated. (a) Heat-treated at $785^{\circ} \mathrm{C}$ for $25 \mathrm{~h}\left(\beta_{\mathrm{Nb}}+\beta \mathrm{Zr}\right.$ separation), (b) heat-treated at $560^{\circ} \mathrm{C} \times 100 \mathrm{~h}\left(\beta_{\mathrm{Nb}}+\alpha_{\mathrm{Zr}}\right.$ separation). ${ }^{28)}$

を用いる。上述の 2 相分離熱処理により硬さが減少するが、 例えば $50 \mathrm{wt} \% \mathrm{Zr}$ 合金ではビッカース硬さは約 210 で、 $90 \%$ の加工で約 270 に硬化する。この值は 2.2 で述べた Nb-Ti 合金より硬く、 $\mathrm{Cu}$ との複合加工が難しくなる。

Fig. 21 に Nb-53 wt\%Zr 合金線の 2 相分離後及び共析分離 後の電子顕微鏡組織を示した。これらの処理で組織が微細 化されて加工方向に引伸され、また $\alpha_{\mathrm{Zr}}$ 相は球状に析出す ることがわかる。 Nb-Zr 合金でも 2 相分離または共析分離 の熱処理、さらにその後の加工によって」 $\mathrm{c}$ がそれぞれ 1 桁 増加する。 $785^{\circ} \mathrm{C}$ での 2 相分離処理の方が $565^{\circ} \mathrm{C}$ での共析分 離処理より若干効果が大きい ${ }^{28)}$ 。この文献は超電導合金で 組織の調整によりJcを高めることを示唆した最初の報告で ある。

$33 \mathrm{wt} \% \mathrm{Zr}$ 及び $50 \mathrm{wt} \% \mathrm{Zr}$ 合金を $8.5 \mathrm{~mm} \phi$ より $0.25 \mathrm{~mm} \phi$ に線引寸る間に 2 回 $785^{\circ} \mathrm{C}$ で熱処理した場合、6 T で〜500 $\mathrm{A} / \mathrm{mm}^{2}$ の J $\mathrm{c}$ を示した。 Nb-Ti 線材より 1 桁 J $\mathrm{c}$ が小さいが $\mathrm{Nb}-\mathrm{Ti}$ 線の場合のように適当な熱処理と加工をさらに繰返 すことにより組織を細かくすれば」 あろう。Nb-Zr 合金線では表面に Cu を厚メッキにより被覆 して $5 \mathrm{~T}$ 程度の磁界を発生する小型のマグネットが多数作 製された。Nb-Zr 合金には添加元素等による $\mathrm{B}_{\mathrm{c} 2}$ と J $\mathrm{c}$ 向上 の余地があると考えられる。

V-Ti 合金の状態図は Nb-Ti 合金に類似しており、加工が 容易でその特性は先に 1960 年代初めに研究された。V 系は $\mathrm{Nb}$ 系より誘導放射能の点ではるかに有利なため、最近また 見直されて V-Ti 合金の特性が研究された ${ }^{29)}$ 。その $\mathrm{T}_{\mathrm{c}}$ は 40 at\%Ti 付近の組成で $8.2 \mathrm{~K}$ で、B $\mathrm{B}_{\mathrm{c} 2}(4.2 \mathrm{~K})$ は $55 \mathrm{at} \% \mathrm{Ti}$ 付近 で $8.5 \mathrm{~T}$ である。J $\mathrm{c}$ は Nb-Ti 合金と同様に $\alpha-\mathrm{Ti}$ 相の析出で 高められ、 $4.2 \mathrm{~K} 、 5 \mathrm{~T}$ で $300 \mathrm{~A} / \mathrm{mm}^{2}$ を超えている。また V-Ti 合金は温度の低下による $\mathrm{B}_{\mathrm{c} 2}$ 上昇の勾配が $\mathrm{Nb}-\mathrm{Ti}$ 合金より 急で、Ta を添加した V-60 at\%Ti-9 at\%Ta 合金は 2 K では $\mathrm{Nb}-60$ at\%Ti 合金を上回る $14 \mathrm{~T}$ の $\mathrm{B}_{\mathrm{c} 2}$ を示す ${ }^{30}$ 。

Mo-Re 合金も加工性に優れ古く関心をもたれ、細線も市 販されて 1961 年に $4.2 \mathrm{~K}$ で $1.5 \mathrm{~T}$ を発生する超電導線を用
いた最初のマグネットが作られた。40６0 wt \%Re 合金は bcc $の ~ \beta$ 相単相であるが、組成により正方晶の $\sigma$ 相が現れ る。 $40 \mathrm{wt} \% \mathrm{Re}$ 付近の組成で $\mathrm{Nb}-\mathrm{Zr}$ を越す $11.3 \mathrm{~K}$ の $\mathrm{T}_{\mathrm{c}}$ を示 寸点が興味深い ${ }^{31}$ 。 。しかしその $\mathrm{B}_{\mathrm{c} 2}$ は低く、 $4.2 \mathrm{~K}$ で $2 \mathrm{~T}$ 程 度にとどまる。Mo-Re 合金は比較的 $\mathrm{T}_{\mathrm{c}}$ が高いので、 $\mathrm{MgB}_{2}$ のように $\rho_{\mathrm{n}}$ を増やせば $\mathrm{B}_{\mathrm{c} 2}$ が高まる可能性があろう。

一方、合金線材を溶解によらないで、次回以降に述心゙る 化合物線材の作製に適用されたような構成金属の棒を束 放て多芯線に加工後熱処理を行って固体拡散で合金化す る方法が試みられている ${ }^{32}$ 。同じ原理で構成金属の薄板を 重祆て圧延したクラッド板を細かくチップ状に切断し、こ れを管につめて押出加工とスエージング加工を繰り返し

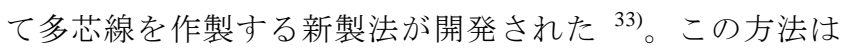
Clad-Chip Extrusion（CCE）法と名付けられ、Fig. 22 にその 原理を示した。合金組成は出発原料の薄板の厚さで調整す

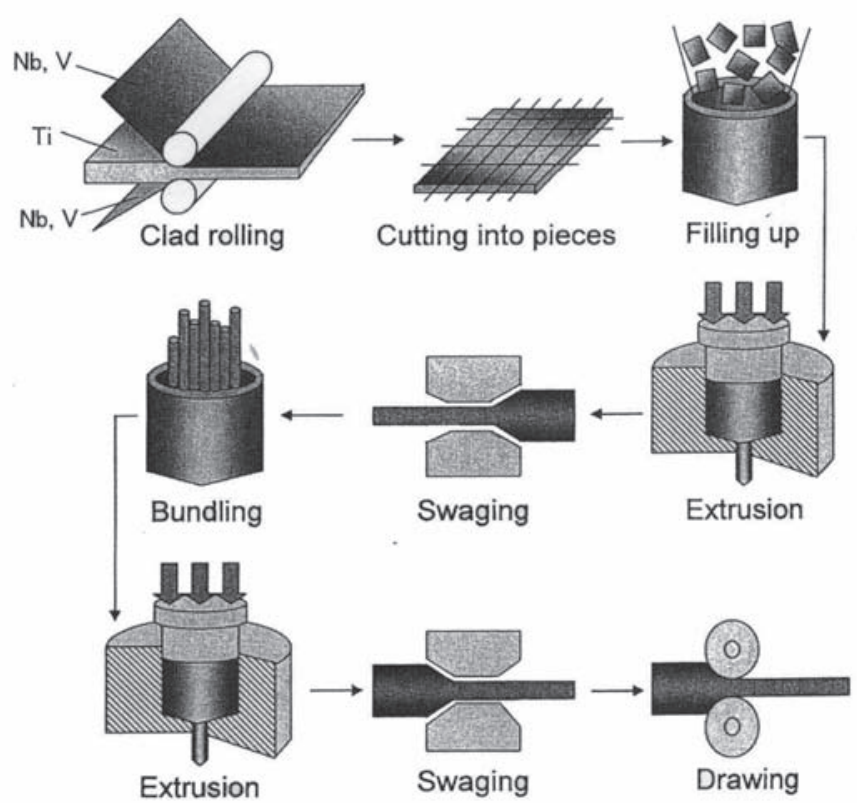

Fig. 22 Fabrication of $\mathrm{Nb}-\mathrm{Ti}$ and $\mathrm{V}-\mathrm{Ti}$ alloy wires using the Clad-Chip Extrusion (CCE) procedure. ${ }^{33)}$ 
ることが出来る。これらの固体拡散による製法は、2.1で 述べた高均一度の合金を作製するためのアーク溶解・鋳造 の繰返しを行う等の手間がない。CCE 法による線材では溶 解法による線材ほどの特性はまだ得られていないが、新し い組成の合金線材の作製や、5.1 で述べた人工ピンの導入 などに有用な手法と注目される。

\section{7. むすび}

合金系線材は加工性がよくて大量生産に向くのが特徵 で、いわばそのキャッチフレーズになっている。その代表 ともいえる Nb-Ti 合金線の需要の主流は MRI であるが、本 稿で述べたように大型の加速器への応用のため、金属組織 と処理の研究に基づき、5〜 $6 \mathrm{~T}$ での J $\mathrm{c}$ 值の向上が急ぎ図ら れた。他面これに伴い大型素材の作製や長尺線材の加工ラ インの確立が促進され、品質管理技術も整備された。従っ て応用からの要求が Nb-Ti 合金線のレベルアップに大きく 貢献し、波及効果を生んだ。

さらに核融合装置等への大容量導体の開発、交流用線材 の開発、 $\mathrm{Al}$ 安定化線材の開発、人工ピンの導入による Jc の向上等の面でも精力的な研究が行われ技術のレベルが 高められた。今後も上記の分野やパルス動作機器、さらに 低温技術の進歩に伴い産業分野へも一層応用が拡大寸る ことを期待したい。

$\mathrm{Nb}-\mathrm{Ti}$ 合金は $\mathrm{Cu}$ との複合加工に適し、また状態図が簡単 で熱処理温度が低くてよいなどの特徽をもっている。これ らの観点から Nb-Ti 合金は欠点の少ない理想に近い組合せ の材料で、それが大きい発展につながったといえる。今そ の組織とJ、について再度新しい観点からじっくり研究して も良い時期にあるのではなかろうか。しかし本質的には $\mathrm{T}_{\mathrm{c}}$ がもう少し高く、Nb-Zr 合金なみになれば応用上楽になる と思われる。

他の合金系材料としては、Nb-Zr 合金は加工性の改善と $\mathrm{B}_{\mathrm{c} 2}$ の向上が望まれる。今後の研究により再び注目される日 が来る余地も残されている。本稿でふれた Mo-Re 合金も興 味ある材料である。将来合金系で新規な材料が出現する可 能性がないとはいえないであろう。

\section{参 考 文 献}

1) K. Tachikawa: "Metallic superconductors [1]", TEION KOGAKU 44(2009) 456-460 (in Japanese)

太刀川恭治：「金属系超伝導線材 [1] ], 低温工学 44 (2009) 456-460

2) Heraeus 社カタログ, PVS-B60 (1985)

3) Allegheny Technology 社、 private communication (2009)

4) T. Shimada, et al.: "Manufacturing of superconducting cable for the LHC-key technology and statistical analysis”, IEEE Trans. Appl. Supercond. 12(2002) 1075-1078

5) 小沼 稔、松本 要:「超伝導材料と線材化技術」、工学図書、 東京（1995）

6) “Binary Alloy Phase Diagrams,” Vol. 3, ASM International (2001)
2777

7) K. Tachikawa, S. Koyama, S. Takahashi and K. Itoh: "The VAMAS intercomparison on the upper critical field measurement in Nb-Ti wire”, IEEE Trans. Appl. Supercond. 5(1995) 536-539

8) A.W. West and D.C. Larbalestier: "Microstructural changes produced in a multifilamentary Nb-Ti composite by cold work and heat treatment”, Metall. Trans. 15A (1984) 843-852

9) P.J. Lee and D.C. Larbalestier: "Development of nanometer scale structures in composites of $\mathrm{Nb}-\mathrm{Ti}$ and their effect on the superconducting critical current density”, Acta Metall. 35 (1987) 2523-2536

10) O.V. Chernyi, et al.: "The microstructure and critical current of $\mathrm{Nb}-48 w \mathrm{w} \% \mathrm{Ti}$ superconductor with very high alpha-Ti precipitate volume and very high critical current”, Advances in Cryogenic Engineering, Vol. 48, AIP, New York (2002) 883-890

11) D.C. Larbalestier, L. Chengren, W. Starch and P.J. Lee: "Limitation of critical current density by intermetallic formation in fine filament Nb-Ti superconductors”, IEEE Trans. Nucl. Sci. NS-32(1985) 3743-3745

12) T. Matsushita: "Flux pinning in superconductors [5]", TEION KOGAKU 44. (2009) 100-111 (in Japanese)

松下照男:「超伝導体における磁束ピンニング[5]」、低温工学 44(2009) 100-111

13) Y. Yamada, S. Murase, H. Wada and K. Tachikawa: "High-field superconducting properties of multifilamentary Nb-Ti-Hf superconductor”, TEION KOGAKU 18 (1983) 256-263 (in Japanese)

山田 穣、村瀬 暁、和田 仁、太刀川恭治：「極細多芯 Nb-Ti-Hf 線の高磁界特性」、低温工学 18(1983) 256-263

14) L.R. Motowidlo, H.C. Katini and B.A. Zeitlin: "NbTi superconductors with artificial pinning structures”, Advances in Cryogenic Engineering (Materials), Vol. 36, Plenum Press, New York (1990) 311-316

15) K. Matsumoto, et al.: "Enhanced $J_{c}$ properties in superconducting $\mathrm{Nb}$ Ti composites by introducing $\mathrm{Nb}$ artificial pins with a layered structure”, Appl. Phys. Lett. 64 (1994) 115-117

16) L.R. Motowidlo, M.K. Rudiziak, T. Wong, L.D. Cooley and P.J. Lee: "Comparison of the properties and microstructure of niobium 47 titanium superconductors with magnetic and non-magnetic island pinning centers”, Advances in Cryogenic Engineering, Vol. 50, AIP, New York (2004) 322-329

17）船木和夫、住吉文夫：「超伝導工学の基礎一多芯線と導体」 産業図書、東京（1995）

18) K. Miyashita, K. Sugiyama, S. Sakai, K. Kamata and H. Chiba: "Nb-Ti superconducting strands with $\mathrm{Cu}-\mathrm{Ni}-\mathrm{Mn}$ matrix and 2kA-class cables for AC use”, Proc. ICEC16/ICMC, Elsevier Science, Oxford (1997)1851-1854

19) K. Tachikawa, S. Koyama, S. Akita, S. Torii, H. Kasahara, Y. Tanaka and K. Matsumoto: "Material and electro-magnetic aspects of newly developed $\mathrm{Nb}-\mathrm{Ti}$ wires for A.C. Use with Cu-Si alloy matrix”, IEEE Trans. Appl. Supercond. 3(1993) 1374-1377

20) O. Miura, et al.: "Development of high-J $\mathrm{c}$ Nb-Ti multifilamentary superconducting wires for AC use by introducing $\mathrm{Nb}$ artificial pins”, TEION KOGAKU 29(1994) 624-636 (in Japanese) 三浦大介ら：「人工ピン型 $\mathrm{NbTi}$ 交流用超電導線材の開発」、 低温工学 29(1994) 624-636

21) H. Kasahara, S. Taniguchi, S. Shimasaki, K. Ueno and K. 
Miyashita: "Electromagnetic stirring of molten gallium using an AC superconducting magnet”, TEION KOGAKU 42 (2007) 395-401 (in Japanese)

笠原奉文、谷口尚司、嶋崎真一、上野和之、宮下克己：「交 流超電導マグネットによる溶融ガリウムの電磁撹抖」、低温 工学 42 (2007) 395-401

22) M.N. Wilson: "Nb-Ti superconductors with low ac loss-a review", Cryogenics 48 (2008) 381-395

23) N. Yanagi and A. Iwamoto: "Development and fabrication of superconducting helical coils for LHD - Development of superconductors for the helical coils of LHD”, TEION KOGAKU 32 (1997) 563-572 (in Japanese)

柳 長門、岩本晃史:「超電導へリカルコイルの開発と製作 一ヘリカル用超電導導体の開発」、低温工学 32(1997) 563-572

24) A. Yamamoto, et al.: "Design and development of the ATLAS central solenoid magnet”, IEEE Trans. Appl. Supercond. 9(1999) 852-855

25) H. Okuno, et al.: “The superconducting ring cyclotron in RIKEN”, IEEE Trans. Appl. Supercond. 17 (2007) 1063-1068

26) A. Yamamoto, M. Nozaki and T. Yoshida: "Bess-Polar: Search for primordial antiparticle by long duration balloon flights at Antarctica”, BUTSURI 58 (2003) 86-93 (in Japanese) 山本 明、野崎光昭、吉田哲也：「Bess Polar: 南極周回気球 実験による宇宙線反粒子の精密探査」、日本物理学会誌 58 (2003) 86-93

27) “Binary Alloy Phase Diagrams”, Vol. 3, ASM International (2001) 2789
28) K. Tachikawa and B. Okai: "Metallurgical aspects and superconducting current capacities of Nb-Zr alloys”, J. Jpn. Inst. Metals 28(1964) 16-21 (in Japanese)

太刀川恭治、岡井 敏：「超電導マグネット材料としての $\mathrm{Nb}-\mathrm{Zr}$ 合金の研究」、日本金属学会誌 28(1964) 16-21

29) M. Tai, K. Inoue, A. Kikuchi, T. Takeuchi, T. Kiyoshi and Y. Hishinuma: "Superconducting properties of V-Ti alloys", IEEE Trans. Appl. Supercond. 17 (2007) 2542-2545

30) K. Inoue, H. Wada, T. Kuroda and K. Tachikawa: "Superconducting properties of V-Ti-Ta ternary alloys”, Proc. ICMC, Kobe, Butterworth, Surrey (1982) 195-198

31) E. Lerner and J.G. Daunt: "Thermal and electrical conductivity of Mo-Re alloys in the superconducting and normal states”, Phys. Rev. 142 (1966) 251-258

32) T. Takeuchi, et al.: "Multifilamentary $\mathrm{Nb}-\mathrm{Zr}$ and $\mathrm{V}-\mathrm{Ti}$ superconducting alloys prepared by diffusion reaction between constituent pure-metal subelements”, Supercond. Sci. Technol. $2 \mathbf{1}$ (2008) 025004 (8pp)

33) S. Saito, et al.: "Fabrication of superconducting alloy wires by Clad-Chip Extrusion method”, J. Jpn. Inst. Metals 71 (2007) 966-971 (in Japanese)

斎藤 栄ら：「クラッド - チップ押出法による合金系超電導 材料の線材化」、日本金属学会誌 71(2007) 966-971

太刀川恭治 第 44 巻 10 号 p.460 参照 